University of South Florida

DIGITAL COMMONS

@ UNIVERSITY OF SOUTH FLORIDA
Digital Commons @ University of

South Florida

7-1-2013

\title{
Rural Transit Fact Book 2013
}

CUTR

Follow this and additional works at: https://digitalcommons.usf.edu/cutr_nctr

\section{Recommended Citation}

"Rural Transit Fact Book 2013," National Center for Transit Research (NCTR) Report No. CUTR-NCTRRR-2013-03, Center for Urban Transportation Research, University of South Florida, 2013.

DOI: https://doi.org/10.5038/CUTR-NCTR-RR-2013-03

Available at: https://scholarcommons.usf.edu/cutr_nctr/98

This Technical Report is brought to you for free and open access by the National Center for Transit Research (NCTR) Archive (2000-2020) at Digital Commons @ University of South Florida. It has been accepted for inclusion in Research Reports by an authorized administrator of Digital Commons @ University of South Florida. For more information, please contact digitalcommons@usf.edu. 


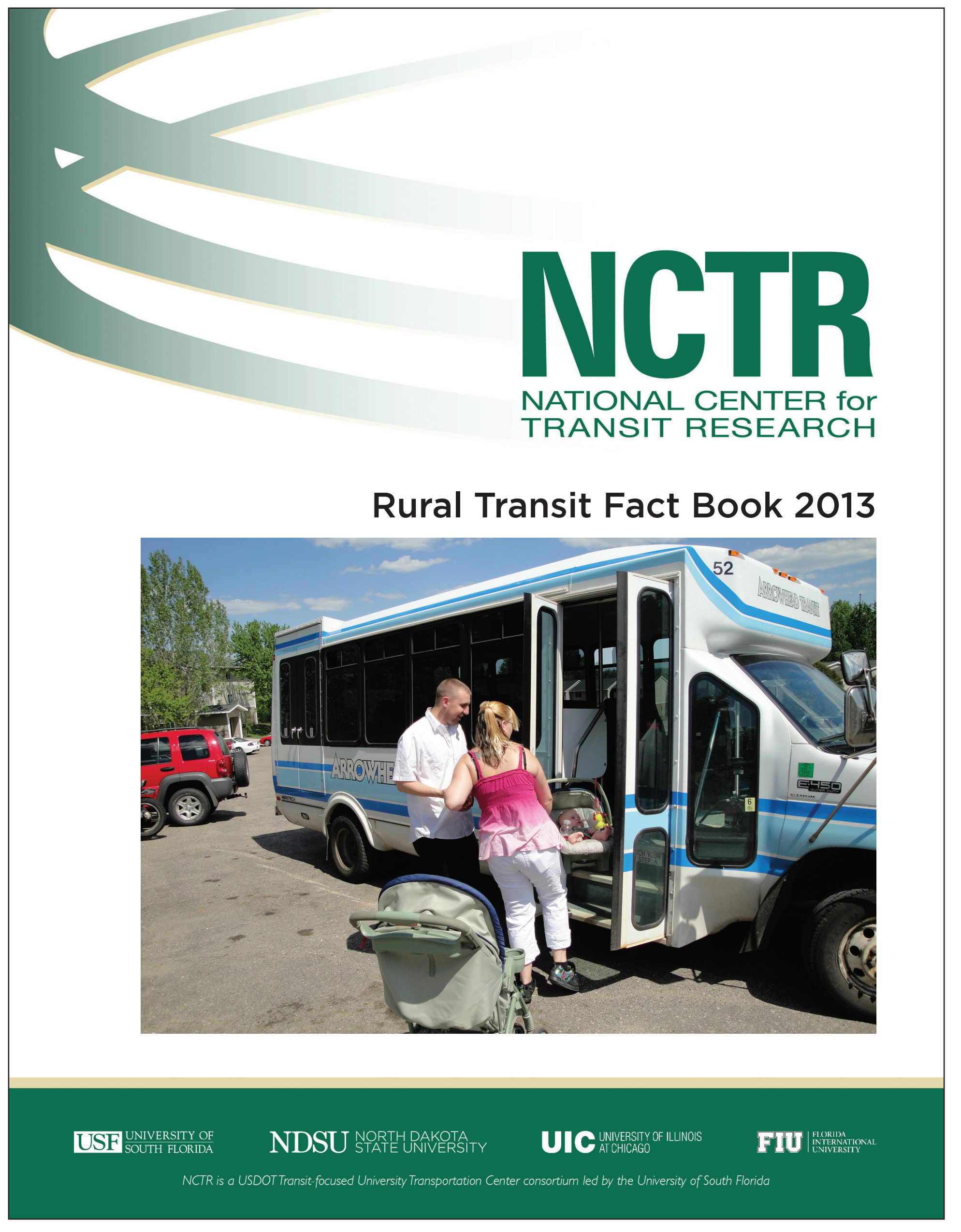




\section{Acknowledgements}

The funds for this study were provided by the United States Department of Transportation through the National Center for Transit Research within the Center for Urban Transportation Research at the University of South Florida. The Small Urban \& Rural Transit Center within the Upper Great Plains Transportation Institute at North Dakota State University conducted the research. This report was written by Jeremy Mattson.

\section{Disclaimer}

The content presented in this report is the sole responsibility of the Small Urban \& Rural Transit Center, the Upper Great Plains Transportation Institute and the authors.

North Dakota State University does not discriminate on the basis of age, color, disability, gender expression/identity, genetic information, marital status, national origin, public assistance status, sex, sexual orientation, status as a U.S. veteran, race or religion. Direct inquiries to the Vice President for Equity, Diversity and Global Outreach, 205 Old Main, (701)231-7708. 


\title{
Rural Transit Fact Book 2013
}

\author{
Prepared for: \\ U.S. Department of Transportation \\ Prepared by: \\ Jeremy Mattson \\ Associate Research Fellow \\ NDSU UPPER GREAT PLAINS \\ North Dakota State University \\ Upper Great Plains Transportation Institute \\ Small Urban and Rural Transit Center \\ Fargo, ND \\ Final Report \\ 21177060-NCTR-NDSU01
}

July 2013

\section{National Center for Transit Research}

A USDOT Transit-focused University Transportation Center consortium led by University of South Florida

4202 E. Fowler Avenue, CUT100, Tampa FL 33620-5375 www.nctr.usf.edu

Member universities: University of South Florida, North Dakota State University,

University of Illinois at Chicago, Florida International University 



\section{CONTENTS}

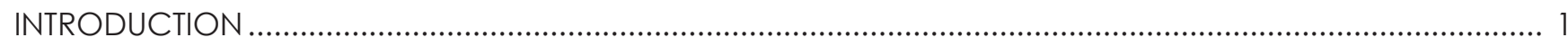

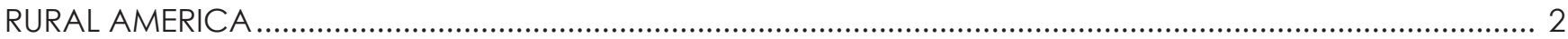

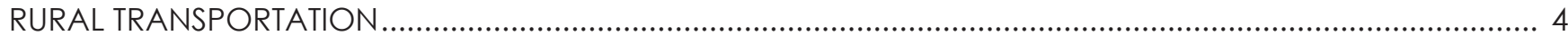

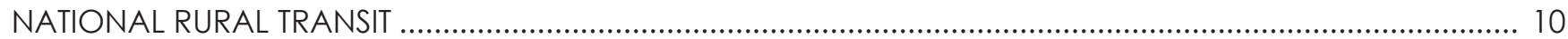

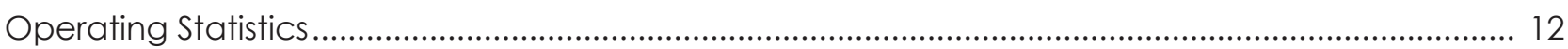

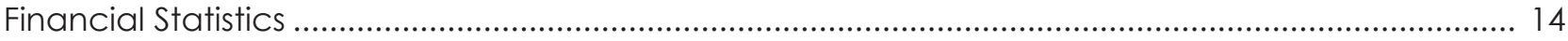

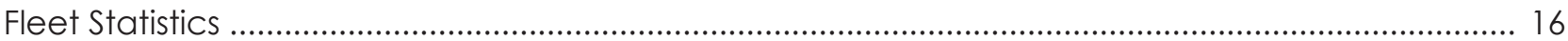

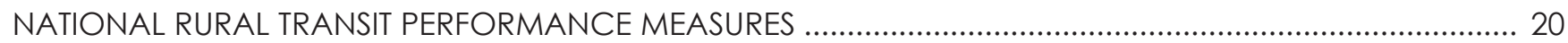

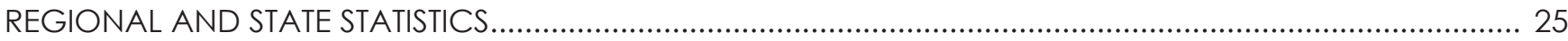

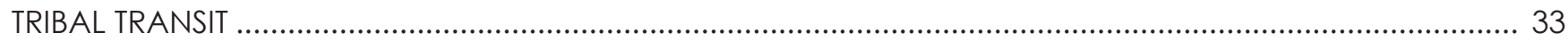

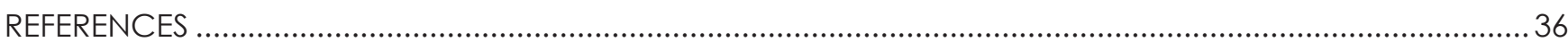




\section{LIST OF TABLES}

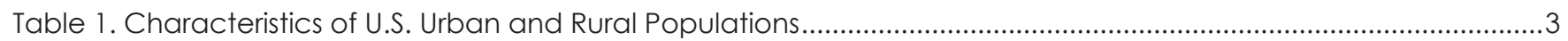

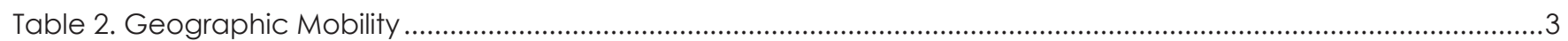

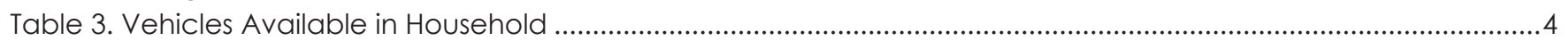

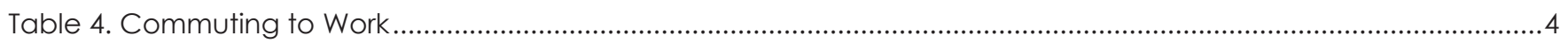

Table 5. Travel Behavior for Urban and Rural Residents, by Age Group .....................................................................

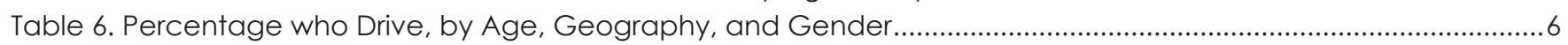

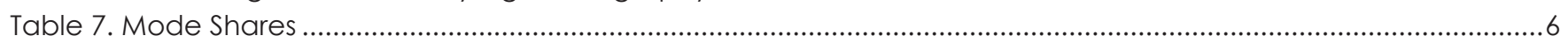

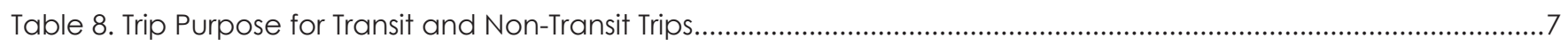

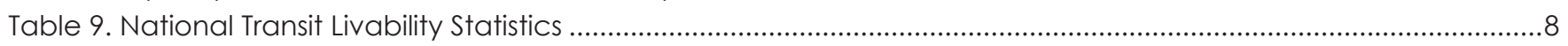

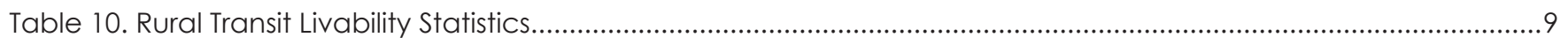

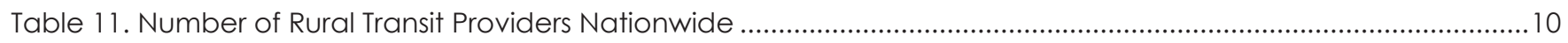

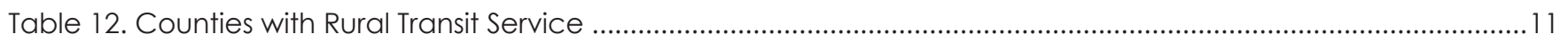

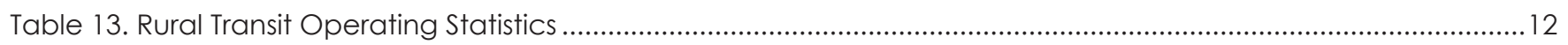

Table 14. Agency Level Changes in Service Miles, Hours, and Trips, 2010-2011 .....................................................13

Table 15. Rural Transit Operating Statistics, Median and Percentile Rankings per Agency, 2011 ...............................14

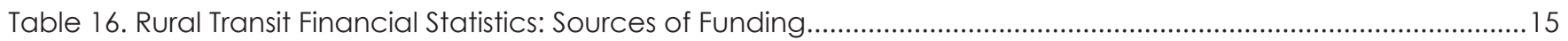

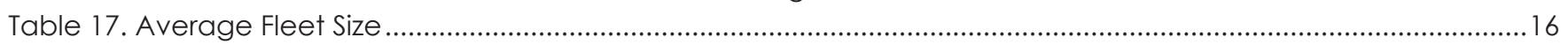

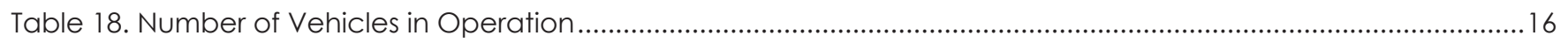

Table 19. Percentage of Rural Transit Vehicles that are ADA Accessible ....................................................................17

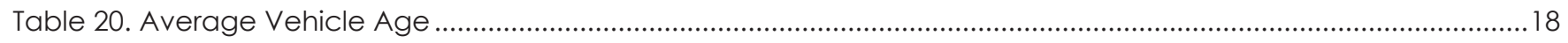

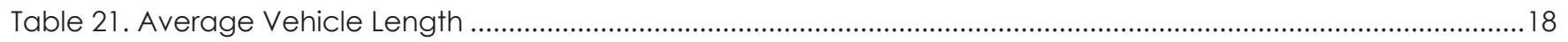

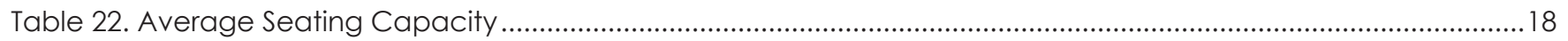

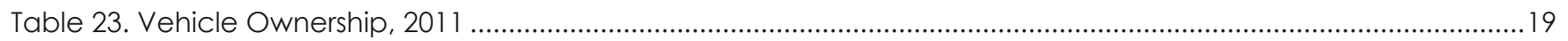

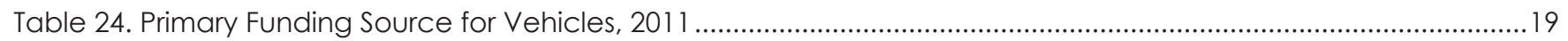

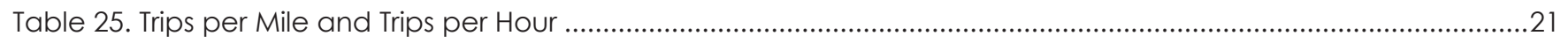

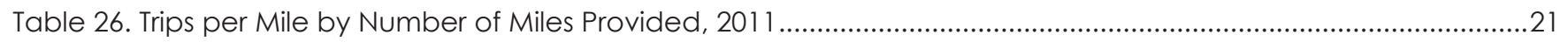

Table 27. Trips per Hour by Number of Hours Provided, 2011 .....................................................................................22

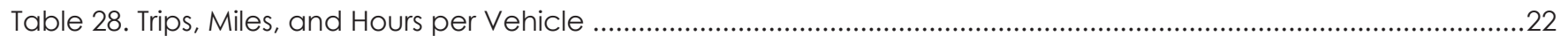

Table 29. Operating Costs per Trip and per Mile and Farebox Recovery Ratio ...........................................................23

Table 30. Operating Costs per Trip and per Mile and Farebox Recovery Ratio, Percentile Rankings, 2011 ..................23

Table 31. Operating Statistics and Performance Measures by Size of Operation, 2011 ...........................................24

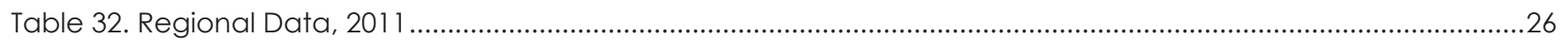

Table 33. Rural Transit Vehicle Revenue Miles of Service by State, 2008-2011 (million miles) .......................................28

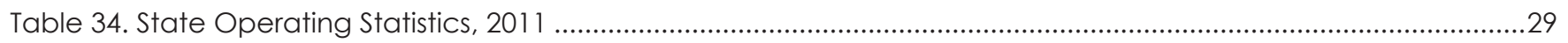

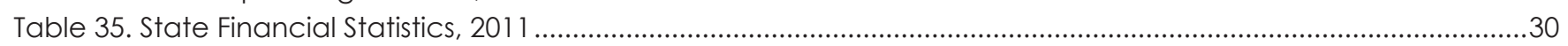

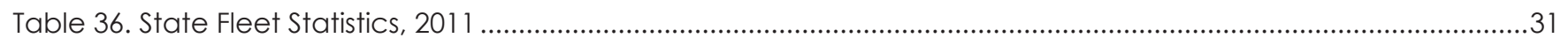

Table 37. State Performance Measures, Median Agency Values, 2011 .......................................................................32

Table 38. Mobility Needs Indicators for Native American and Alaska Native Communities .........................................33

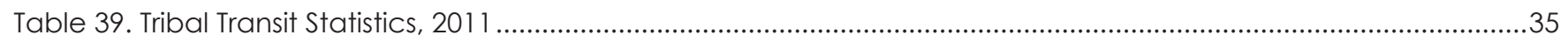

\section{LIST OF FIGURES}

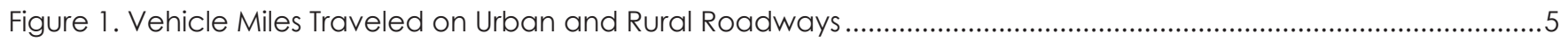

Figure 2. Percentage of Trips by Public Transportation, by Size of Metro Area ….........................................................

Figure 3. FTA Spending under the Section 5311 Program, 2005-2010 ......................................................................16

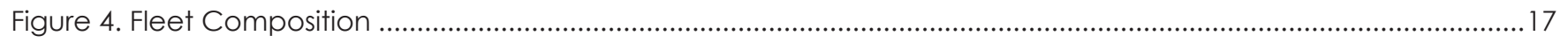

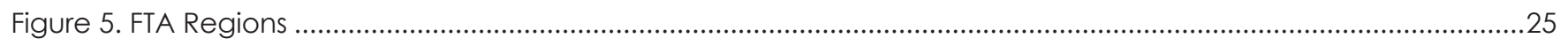

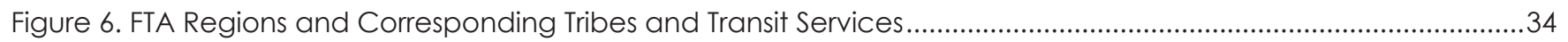




\section{INTRODUCTION}

Public transportation plays a fundamental role in the livability of all communities. Information on transit service availability and cost is necessary to efficiently and effectively meet rural community mobility needs. Financial and operating statistics can be used by agency managers, local decision makers, state directors, the Federal Transit Administration (FTA), and lawmakers to assist in policy making, planning, managing operations, and evaluating performance. The Rural Transit Fact Book provides information to assist the transit industry in the United States provide efficient and effective service to rural communities.

The intent of the Rural Transit Fact Book is to serve as a national resource for statistics and information on rural transit in America. This publication includes rural demographic and travel behavior data as well as financial and operating statistics for agencies receiving section 5311 funding. In addition to national level data, statistics are presented by state, FTA region, tribe, and mode, as well as other agency characteristics.

The rural transit data presented in this report were obtained from the Rural National Transit Database (NTD). The 2011 edition of the Rural Transit Fact Book was the first published by SURTC and included Rural NTD data for 2007-2009. The 2012 edition updated the original Fact Book with the addition of 2010 data, and this publication, the 2013 edition, includes 2011 data from the Rural NTD as well as additional data from the American Housing Survey and the National Household Travel Survey.

SURTC is not responsible for the accuracy of the data reported to the Rural NTD. Over time, it is expected that the quality of data contained in the Rural NTD will improve in terms of completeness and accuracy as the FTA raises data concerns with states who in turn receive better data from subrecipients.

As noted, this publication presents data for transit providers receiving section 5311 Non-Urbanized Area Formula Program funding. This program provides funding to states for the purpose of supporting public transportation in rural areas with a population of less than 50,000. A number of rural transit providers also receive funding under the section 5310, Transportation for Elderly Persons and Persons with Disabilities, program. However, nationwide data for 5310 services are not available, as providers are not required to report such data to the NTD. Therefore, rural transit providers not funded by the 5311 program but receiving funding from section 5310 are not included in this report. 


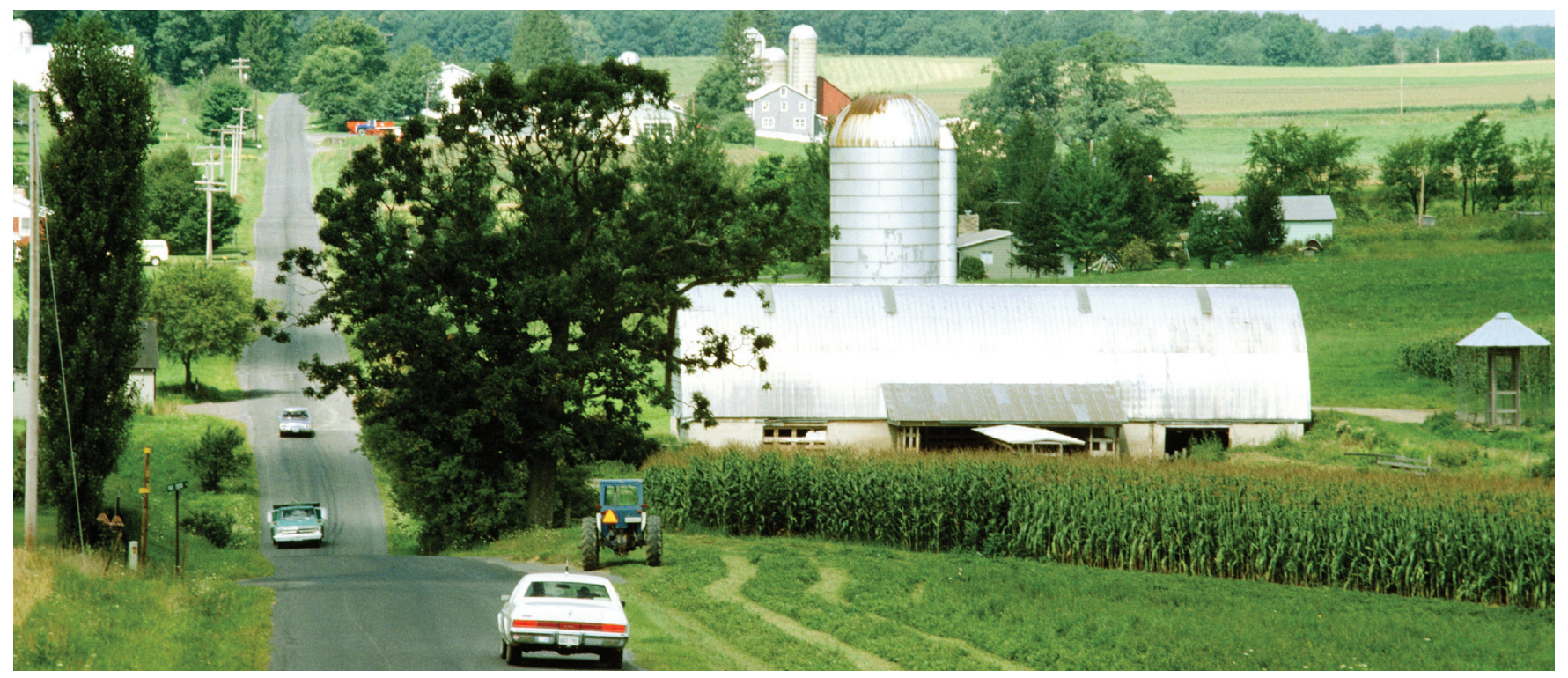

\section{RURAL AMERICA}

Geography influences the type and level of transit service that best serves a community. About 75 million Americans, or close to a quarter of the country's population, live in rural areas, according to data from the American Community Survey (ACS). Table 1 shows select demographic data from the 2009-2011 ACS 3-year estimates for the United States and for urban and rural areas. As defined by the ACS, urban includes urban areas and urban clusters. Urbanized areas have 50,000 or more people and urban clusters have at least 2,500 people but less than 50,000 people, and both areas have a core area with a density of at least 1,000 people per square mile. All other areas are defined as rural.

Rural populations tend to be slightly older. The median age is 40 in rural areas and 36 in urban areas. Approximately $14 \%$ of residents in rural areas are 65 or older, compared to $13 \%$ of those in urban areas. On the other hand, urban areas have a slightly higher percentage of residents aged 85 or older (1.9\%) than do rural areas (1.4\%). The percentage of people with disabilities is slightly higher in rural areas (13\%) than in urban areas (12\%).

Rural areas tend to be less ethnically diverse. Urban residents are more likely than their rural counterparts to be non-white or Hispanic, and the foreign-born population is much higher in urban areas (15\%) than in rural areas (5\%).

Education levels vary somewhat between urban and rural communities. The percentage of individuals that have completed high school in rural areas is about the same, or slightly higher, than that for urban areas, but urban areas tend to have a higher percentage of residents with a bachelor's or advanced degree.

Median household income is slightly higher in rural areas, and a higher percentage of urban residents live below the poverty line. Rural residents are much more likely to own their house, and both mortgageowners and renters in rural areas spend a lower percentage of their income on housing than do their urban counterparts.

Urban residents tend to have greater geographic mobility than those in rural areas (see Table 2). That is, they are less tied to a geographic area and are more likely to move. About $17 \%$ of urban residents have moved during the last year, compared to $11 \%$ of rural residents. Urban residents are also more likely to make longer moves, and rural residents are more likely than those in urban areas to live in the state in which they were born. 
Table 1. Characteristics of U.S. Urban and Rural Populations

\begin{tabular}{|c|c|c|c|}
\hline & $\begin{array}{l}\text { United } \\
\text { States }\end{array}$ & Urban & Rural \\
\hline Total Population (million people) & 309 & 234 & 75 \\
\hline Average household size & 2.62 & 2.61 & 2.66 \\
\hline \multicolumn{4}{|l|}{ Gender (\%) } \\
\hline Male & 49.2 & 48.8 & 50.3 \\
\hline Female & 50.8 & 51.2 & 49.7 \\
\hline \multicolumn{4}{|l|}{ Age } \\
\hline Median Age & 37.2 & 36.1 & 40.2 \\
\hline 65 or older (\%) & 13.1 & 12.8 & 14.1 \\
\hline 85 or older (\%) & 1.8 & 1.9 & 1.4 \\
\hline Population with a Disability (\%) & 12.0 & 11.6 & 13.2 \\
\hline \multicolumn{4}{|l|}{ Race (\%) } \\
\hline White & 76.4 & 72.7 & 88.1 \\
\hline Black or African-American & 13.6 & 15.6 & 7.3 \\
\hline American Indian and Alaska Native & 1.6 & 1.4 & 2.3 \\
\hline Asian & 5.6 & 6.6 & 2.2 \\
\hline Hispanic or Latino & 16.4 & 19.3 & 7.4 \\
\hline Foreign Born (\%) & 12.9 & 15.5 & 4.8 \\
\hline \multicolumn{4}{|l|}{ Education Level Completed (\%) } \\
\hline High school & 85.5 & 85.2 & 86.5 \\
\hline Bachelor's degree & 28.2 & 30.0 & 22.9 \\
\hline Advanced degree & 10.5 & 11.3 & 8.0 \\
\hline \multicolumn{4}{|l|}{ Economic Characteristics } \\
\hline Individuals below the poverty line (\%) & 15.2 & 16.1 & 12.2 \\
\hline Median household income (thousand dollars) & 51.5 & 50.9 & 53.2 \\
\hline
\end{tabular}

Table 2. Geographic Mobility

\begin{tabular}{lccc}
\hline & $\begin{array}{l}\text { United } \\
\text { States }\end{array}$ & Urban & Rural \\
\hline & -------- percentage & -------- \\
Native population born in their state of & 58.7 & 56.4 & 66.0 \\
residence & 15.3 & 16.6 & 11.4 \\
Lived in a different house one year ago & & & \\
Lived in a different state or abroad one & 2.9 & 3.1 & 2.2 \\
year ago & & & \\
\hline Source: American Community Survey 2009-2011 &
\end{tabular}

Source: American Community Survey 2009-2011 


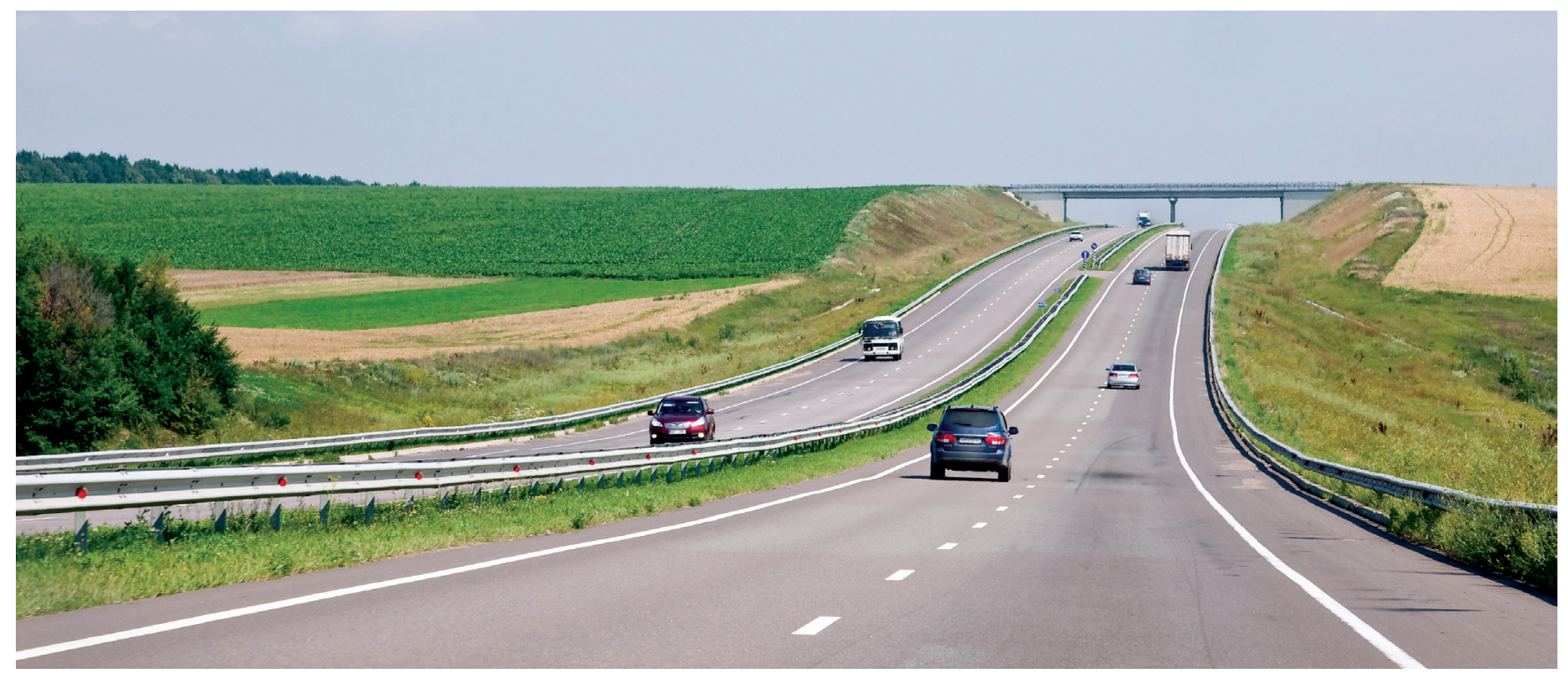

\section{RURAL TRANSPORTATION}

Data from the ACS, Federal Highway Administration (FHWA), and National Household Travel Survey (NHTS) show there are some differences in transportation and travel behavior between urban and rural areas. One notable difference is a greater reliance on automobiles by rural residents (see Tables 3-7). Just $4 \%$ of rural households do not have a vehicle available, compared to $11 \%$ of urban households. Meanwhile, $71 \%$ of rural households have two or more vehicles, while only $53 \%$ of urban households have two or more vehicles.

Rural workers are more likely to drive alone to work and less likely to commute by public transportation than those in urban areas. Fewer than $1 \%$ of rural residents use public transportation to travel to work, compared to $6 \%$ of urban residents. Only $1.5 \%$ of rural workers aged 16 or older do not have access to a vehicle, compared to $5.3 \%$ of their urban counterparts. Rural residents also tend to have slightly longer commutes (measured in minutes).

Table 3. Vehicles Available in Household

\begin{tabular}{|c|c|c|c|}
\hline & $\begin{array}{l}\text { United } \\
\text { States }\end{array}$ & Urban & Rural \\
\hline & \multicolumn{3}{|c|}{ percentage } \\
\hline None & 9.1 & 10.7 & 3.8 \\
\hline 1 & 33.8 & 36.4 & 25.4 \\
\hline 2 & 37.6 & 36.1 & 42.1 \\
\hline 3 or more & 19.6 & 16.7 & 28.7 \\
\hline
\end{tabular}

Table 4. Commuting to Work

\begin{tabular}{lrrr}
\hline & $\begin{array}{c}\text { United } \\
\text { States }\end{array}$ & Urban & Rural \\
\hline Mode Used & & & \\
Car, truck, or van - drove alone & $76.4 \%$ & $74.8 \%$ & $81.4 \%$ \\
Car, truck, or van - carpooled & $9.8 \%$ & $9.8 \%$ & $9.9 \%$ \\
Public transportation (excluding taxicab) & $5.0 \%$ & $6.3 \%$ & $0.6 \%$ \\
Walked & $2.8 \%$ & $3.1 \%$ & $1.8 \%$ \\
Other means & $1.7 \%$ & $1.9 \%$ & $1.2 \%$ \\
Worked at home & $4.3 \%$ & $4.0 \%$ & $5.2 \%$ \\
Mean travel time to work (minutes) & 25.3 & 24.8 & 26.9 \\
\hline
\end{tabular}

Source: American Community Survey 2009-2011 
Despite heavy reliance on automobiles, vehicle miles traveled (VMT) on rural roads has been slowly declining over the past decade (see Figure 1). VMT on urban roads, on the other hand, had been steadily increasing until dropping or leveling off after 2007. VMT on both urban and rural roads was mostly unchanged from 2011 to 2012. The VMT depicted in Figure 1 includes both personal and commercial travel and is total VMT, as opposed to per capita VMT.

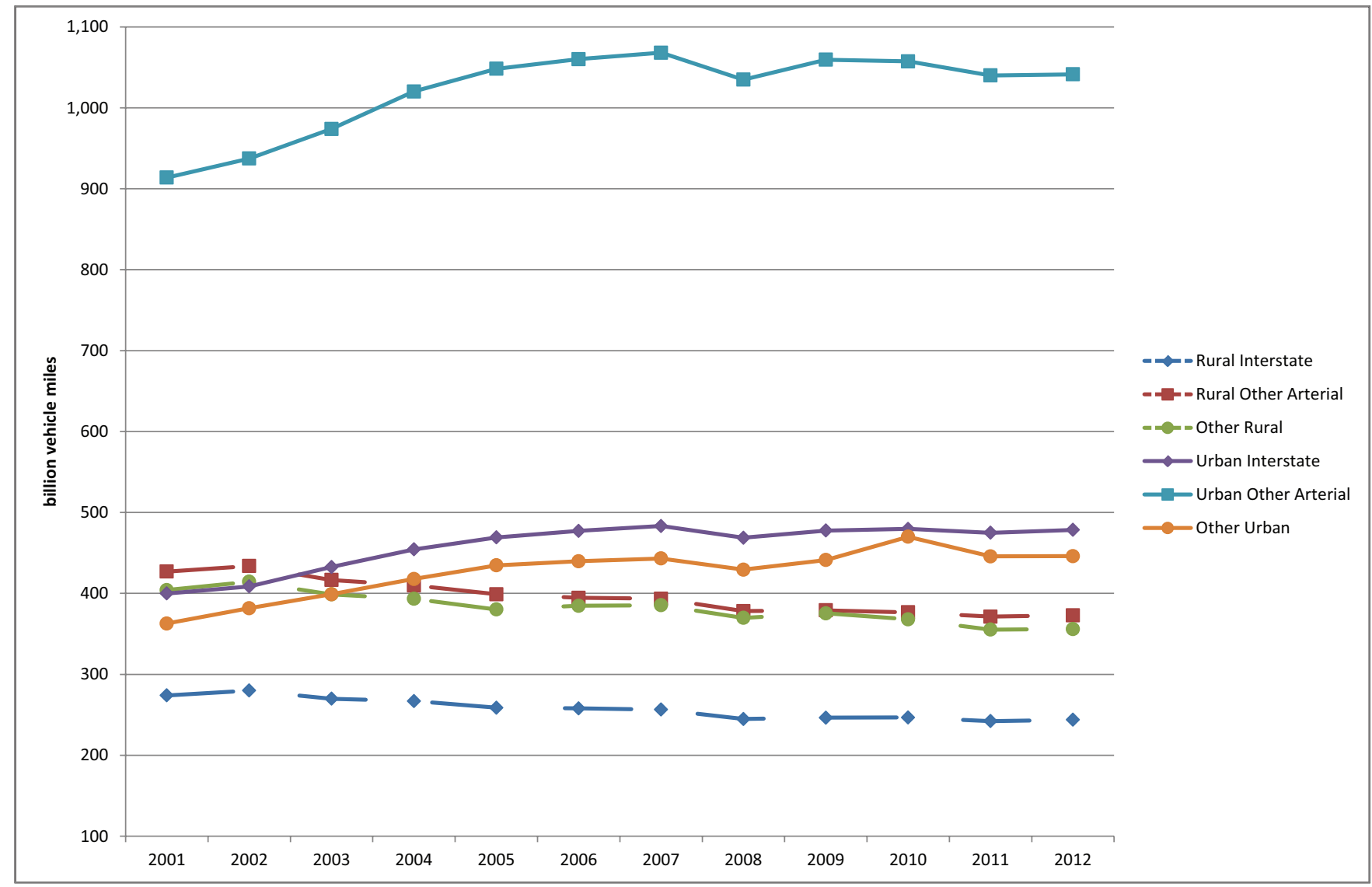

Figure 1. Vehicle Miles Traveled on Urban and Rural Roadways

Source: Federal Highway Administration

The NHTS contains a variety of statistics on travel behavior. The NHTS is a periodic national survey sponsored by the Bureau of Transportation Statistics and the FHWA. The most recent NHTS was conducted in 2009. The dataset also classifies respondents as urban or rural using the same definition used by the ACS.

Data from the NHTS show that rural residents drive more, on average, than their urban counterparts; are less likely to use public transportation; and drive vehicles that tend to be a bit older with more miles and have slightly lower fuel economy. Table 5 provides data on differences in trips per day, VMT, and use of transit between urban and rural residents by age group. Urban residents, on average, make more trips per day. Although urban residents may make more trips, the distance traveled per individual trip is longer in rural areas. As shown in the 2011 Rural Transit Fact Book, the average distance per trip is 8.9 miles in urban areas and 12.5 miles in rural areas, and the median distances for urban and rural residents is 3 miles and 6 miles, respectively. As a result of longer trip distances and greater reliance on the automobile, rural residents drive more miles per year than their urban counterparts. As shown in Table 5, annual VMT per person peaks for those in the 34-49 age group at 15,079 miles for rural residents and 10,999 miles for urban residents. 
Table 5. Travel Behavior for Urban and Rural Residents, by Age Group

\begin{tabular}{|c|c|c|c|c|c|c|}
\hline \multirow[b]{2}{*}{ Age } & \multicolumn{2}{|c|}{$\begin{array}{l}\text { Number of Trips } \\
\text { Per Travel Day }\end{array}$} & \multicolumn{2}{|c|}{$\begin{array}{c}\text { Annual VMT Per } \\
\text { Person }\end{array}$} & \multicolumn{2}{|c|}{$\begin{array}{c}\text { Used Transit on } \\
\text { Travel Day }\end{array}$} \\
\hline & Urban & Rural & Urban & Rural & Urban & Rural \\
\hline $19-33$ & 3.9 & 3.6 & 7,898 & 12,246 & $7.8 \%$ & $1.0 \%$ \\
\hline $34-49$ & 4.4 & 4.0 & 10,999 & 15,079 & $5.9 \%$ & $0.7 \%$ \\
\hline $50-64$ & 4.1 & 3.9 & 9,412 & 13,862 & $5.6 \%$ & $0.8 \%$ \\
\hline $65-74$ & 3.7 & 3.5 & 6,458 & 9,735 & $4.0 \%$ & $0.4 \%$ \\
\hline$>74$ & 2.7 & 2.7 & 3,459 & 5,535 & $3.8 \%$ & $0.7 \%$ \\
\hline
\end{tabular}

Source: 2009 National Household Travel Survey

Driving rates are shown in Table 6 to be higher in rural areas. For example, $96 \%$ of men and $95 \%$ of women aged $19-64$ in rural areas drive, compared to $93 \%$ of men and $90 \%$ of women of similar age in urban areas. A significant difference is also shown for older women, as $82 \%$ of women 65 or older drive in rural areas, compared to $71 \%$ of similarly aged women in urban areas.

Table 6. Percentage Who Drive by Age, Geography, and Gender

\begin{tabular}{ccccc}
\hline & \multicolumn{2}{c}{ Urban } & \multicolumn{2}{c}{ Rural } \\
\hline Age & Male & Female & Male & Female \\
\hline $19-64$ & 93.2 & 89.6 & 95.6 & 95.0 \\
$65+$ & 87.3 & 70.5 & 92.8 & 82.0 \\
$65-74$ & 91.7 & 82.0 & 96.2 & 91.1 \\
$75-84$ & 86.3 & 67.0 & 90.9 & 74.9 \\
$85+$ & 68.4 & 38.3 & 63.6 & 40.9 \\
\hline
\end{tabular}

Source: 2009 National Household Travel Survey

Differences in mode shares are illustrated in Table 7 and Figure 2, which shows how the percentage of trips made by public transportation increases from rural to larger urban areas. In non-metro areas, just $0.4 \%$ of trips are made by public transportation, while $4.6 \%$ of trips are made by public transportation in metro areas with a population of 3 million or more.

Table 7. Mode Shares

\begin{tabular}{lccr}
\hline & Total & Urban & Rural \\
\hline Auto & ------- & percentage & --------- \\
Transit & 85.1 & 83.6 & 90.3 \\
Bicycle & 2.3 & 2.9 & 0.4 \\
Walking & 0.7 & 0.8 & 0.5 \\
Source: 2009 National Household Travel Survey & 10.0 & 11.0 & 6.4 \\
\hline
\end{tabular}




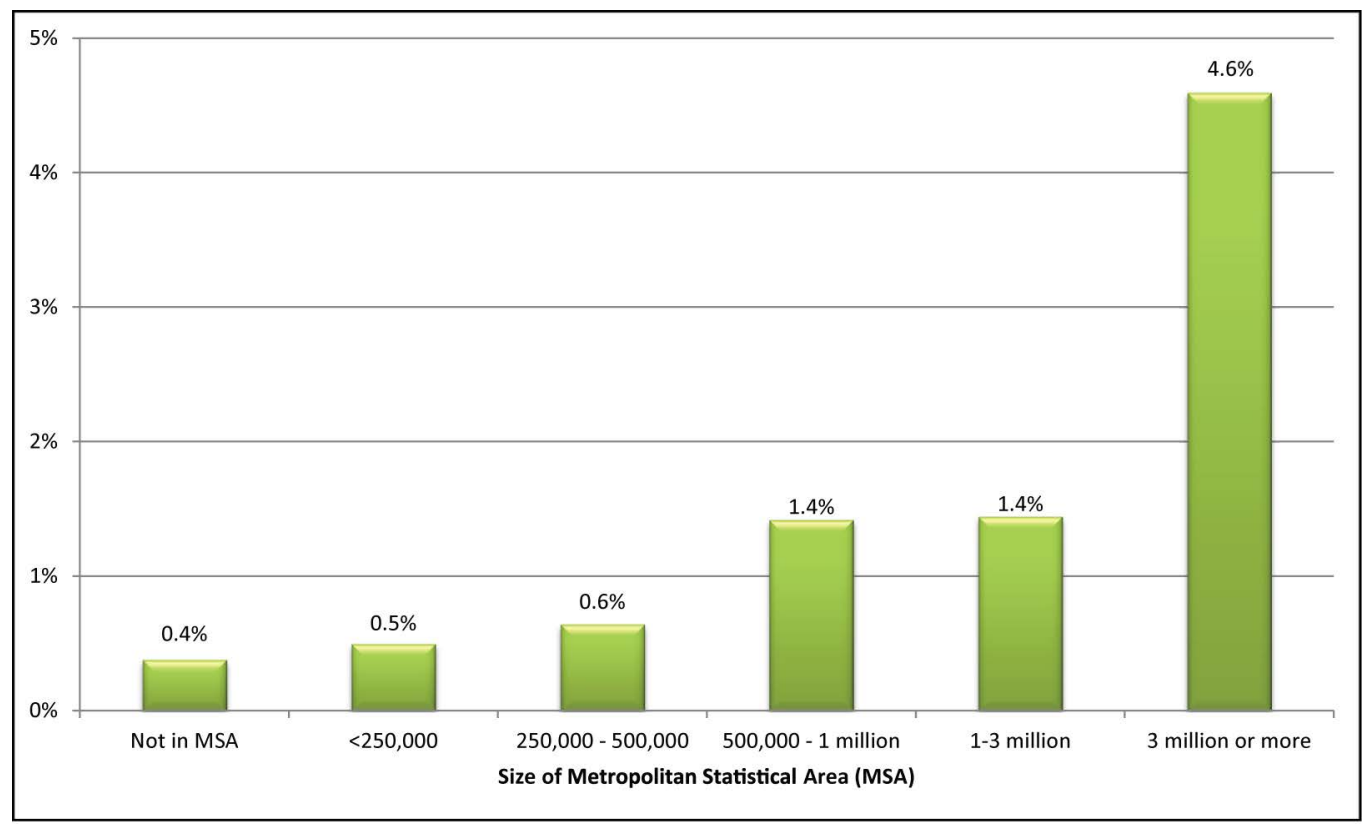

Figure 2. Percentage of Trips by Public Transportation, by Size of Metro Area Source: 2009 National Household Travel Survey

Table 8 shows the general purposes for transit and non-transit trips in urban and rural areas, according to data from the NHTS. For rural transit trips, the highest percentage of trips is for work or school/church. Medical trips account for $7.4 \%$ of transit trips in rural areas, but only $2.4 \%$ of non-transit trips are for medical, indicating a higher propensity for these types of trips to be made by transit. Other reports have found a higher percentage of rural transit trips being for medical purposes. Based on a study of on-board surveys, the American Public Transportation Association (APTA) (2007) found that in areas with a population below $200,000,8.6 \%$ of transit trips are for medical purposes. These percentages vary significantly between individual transit providers depending on the type of service provided. Some rural transit systems provide a significantly higher percentage of trips for medical purposes, while others provide a higher percentage of work trips.

The data indicate that work, school, and medical trips comprise a much higher percentage of transit trips than non-transit trips, and the opposite is true tor shopping and social.

Table 8. Trip Purpose for Transit and Non-Transit Trips

\begin{tabular}{|c|c|c|c|c|}
\hline \multirow[b]{2}{*}{ Trip Purpose } & \multicolumn{2}{|c|}{ Transit Trips } & \multicolumn{2}{|c|}{ Non-Transit Trips } \\
\hline & Urban & Rural* & Urban & Rural \\
\hline & \multicolumn{4}{|c|}{--------------- Percentage --------------- } \\
\hline Work & 27.3 & 27.4 & 15.3 & 16.5 \\
\hline Work-related business & 4.0 & 1.7 & 2.8 & 4.0 \\
\hline Shopping & 17.6 & 7.8 & 21.3 & 20.9 \\
\hline Other personal/business & 9.7 & 11.5 & 19.5 & 19.1 \\
\hline School/church & 10.4 & 20.4 & 9.6 & 9.7 \\
\hline Medical/dental & 6.3 & 7.4 & 2.5 & 2.4 \\
\hline Vacation & 1.6 & 4.7 & 1.1 & 1.2 \\
\hline Visit friends/relatives & 6.6 & 4.3 & 6.7 & 7.3 \\
\hline Other social/recreational & 12.2 & 12.3 & 20.4 & 18.3 \\
\hline Other & 4.4 & 2.5 & 0.7 & 0.6 \\
\hline
\end{tabular}

*Transit in rural areas is defined to include just bus and paratransit.

Source: 2009 National Household Travel Survey 
The American Housing Survey (AHS) is another data source providing information on availability and use of transit services in urban and rural areas. The AHS is a survey funded by the U.S. Department of Housing and Urban Development (HUD) and conducted by the U.S. Census Bureau in odd-numbered years.

This survey collects data on transportation alternatives and travel behavior, including transit availability, accessibility, desirability, and use. A recent SURTC study (Ripplinger et al. 2012) used data from the AHS to calculate a series of transit livability statistics, with the intent of investigating and measuring the relationship between transit and community livability. A few of the findings from this report are published in Tables 9 and 10. The measures shown in these tables were calculated as follows:

Transit Availability: The percentage of individuals who live in neighborhoods where transit is available.

Transit Accessibility: The average travel time from an individual's residence to the nearest transit stop in the case where transit is available. Travel time is measured via whichever mode the individual uses, which may include walking or some other mode.

Transit Use: The percentage of individuals who live in households where transit was used by at least one household member in the past week.

Transit Desirability: The percentage of individuals who chose their current housing unit because it was close to transit.

Vehicle Availability: The percentage of individuals who live in a household with at least one vehicle available.

The statistics in Table 9 show how transit availability, accessibility, desirability, and use vary between urban, suburban, small urban, and rural areas. For example, transit was shown to be available to $13 \%$ of rural residents, compared to a national average of $57 \%$. Data specific to rural areas are shown in Table 10, with difference shown between regions and individual characteristics.

Table 9. National Transit Livability Statistics

\begin{tabular}{lccccc}
\hline & $\begin{array}{c}\text { Transit } \\
\text { Availability }\end{array}$ & $\begin{array}{c}\text { Transit } \\
\text { Accessibility }\end{array}$ & $\begin{array}{c}\text { Transit } \\
\text { Use }\end{array}$ & $\begin{array}{c}\text { Transit } \\
\text { Desirability }\end{array}$ & $\begin{array}{c}\text { Vehicle } \\
\text { Availability }\end{array}$ \\
\hline National & $57 \%$ & $6: 06$ & $20 \%$ & $5 \%$ & $94 \%$ \\
MSA-City Center & $86 \%$ & $5: 15$ & $28 \%$ & $8 \%$ & $87 \%$ \\
MSA-Suburban & $66 \%$ & $6: 36$ & $15 \%$ & $5 \%$ & $96 \%$ \\
MSA-Rural & $22 \%$ & $8: 24$ & $9 \%$ & $2 \%$ & $98 \%$ \\
Small Urban & $37 \%$ & $5: 55$ & $10 \%$ & $1 \%$ & $94 \%$ \\
Rural & $13 \%$ & $8: 11$ & $9 \%$ & $0 \%$ & $97 \%$ \\
\hline
\end{tabular}

Source: 2009 American Housing Survey 
Table 10. Rural Transit Livability Statistics

\begin{tabular}{|c|c|c|c|c|c|}
\hline & $\begin{array}{c}\text { Transit } \\
\text { Availability }\end{array}$ & $\begin{array}{c}\text { Transit } \\
\text { Accessibility }\end{array}$ & $\begin{array}{c}\text { Transit } \\
\text { Use }\end{array}$ & $\begin{array}{c}\text { Transit } \\
\text { Desirability }\end{array}$ & $\begin{array}{c}\text { Vehicle } \\
\text { Availability }\end{array}$ \\
\hline Rural Total & $13 \%$ & $8: 11$ & $9 \%$ & $0 \%$ & $97 \%$ \\
\hline \multicolumn{6}{|l|}{ Region } \\
\hline Northeast & $16 \%$ & 8:02 & $13 \%$ & $0 \%$ & $97 \%$ \\
\hline Midwest & $15 \%$ & $5: 39$ & $8 \%$ & $1 \%$ & $97 \%$ \\
\hline South & $8 \%$ & $12: 32$ & $3 \%$ & $0 \%$ & $97 \%$ \\
\hline West & $25 \%$ & $6: 50$ & $13 \%$ & $1 \%$ & $98 \%$ \\
\hline \multicolumn{6}{|l|}{ Individual Characteristics } \\
\hline Low-income & $17 \%$ & 10:31 & $13 \%$ & $1 \%$ & $89 \%$ \\
\hline Senior & $13 \%$ & $8: 24$ & $7 \%$ & $0 \%$ & $96 \%$ \\
\hline Male & $13 \%$ & $8: 33$ & $9 \%$ & $0 \%$ & $98 \%$ \\
\hline $\begin{array}{l}\text { Receiving disability } \\
\text { payments }\end{array}$ & $13 \%$ & 7:08 & $16 \%$ & $0 \%$ & $97 \%$ \\
\hline
\end{tabular}

Source: 2009 American Housing Survey 


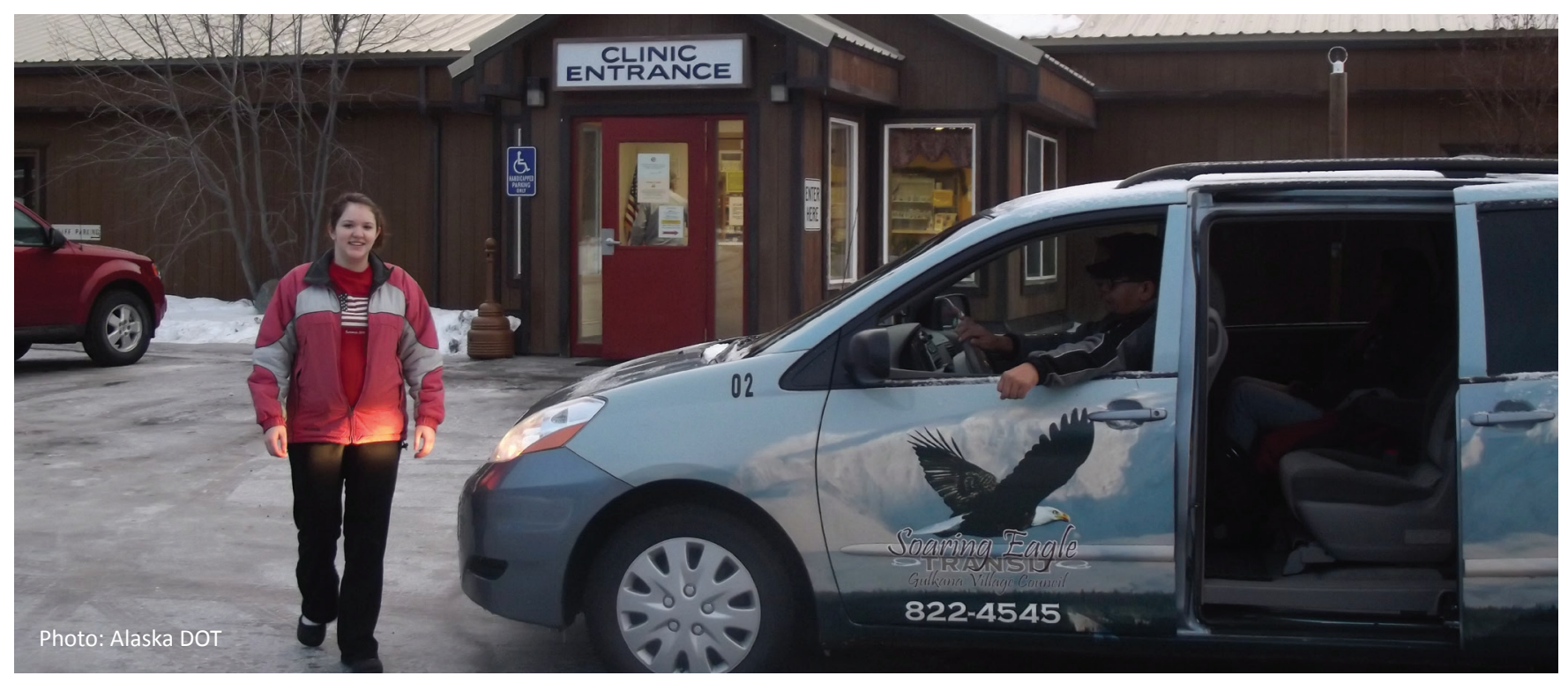

\section{NATIONAL RURAL TRANSIT}

This section describes the characteristics of rural transit systems receiving section 5311 funding, using data submitted by these systems to the Rural NTD. The Rural NTD began collecting data in 2007. Data for 2011 are the most recent data available at the time of publication.

The number of agencies providing rural transit service, as reported in the Rural NTD, decreased slightly from 1,403 in 2010 to 1,392 in 2011 (see Table 11).

Many of these agencies offer strictly a demand-response service, while 262 offer both demandresponse and fixed-route, and some offer just fixed-route. ' A total of 464 systems provided fixed-route service in 2011, including either a traditional fixed-route service or deviated fixed-routes.

Table 11. Number of Rural Transit Providers Nationwide

\begin{tabular}{lrrrr}
\hline & 2008 & 2009 & 2010 & 2011 \\
\hline Total & 1,358 & 1,358 & 1,403 & 1,392 \\
Type of Service Offered: & & & & \\
Total fixed-route & 440 & 429 & 472 & 464 \\
$\quad$ Traditional fixed-route & 225 & 243 & 246 & 238 \\
$\quad$ Deviated fixed-route & 287 & 278 & 302 & 297 \\
$\quad$ Both & 72 & 92 & 76 & 71 \\
Demand-response & 1,149 & 1,169 & 1,180 & 1,121 \\
Demand-response \& fixed-route & 228 & 235 & 253 & 262 \\
Demand-response taxi & - & - & - & 78 \\
Ferryboat & - & - & - & 4 \\
Commuter bus & - & - & - & 58 \\
Van pool & 16 & 14 & 16 & 18 \\
Other not specified & 40 & 22 & 21 & 15 \\
\hline
\end{tabular}

Source: Rural National Transit Database, 2008-2011

\footnotetext{
${ }^{1}$ Although the Americans with Disabilities Act (ADA) requires transit agencies to provide paratransit services that complement their fixed-route services, it is not required for those that provide deviated fixed-route or commuter bus services. Many of those agencies identified as offering just fixedroute service provide these types of services, and some may actually provide demand-response paratransit but did not have the data reported.
} 
Table 12. Counties with Rural Transit Service

\begin{tabular}{|c|c|c|c|c|c|}
\hline \multirow[b]{2}{*}{ State } & \multirow{2}{*}{$\begin{array}{c}\text { Number of } \\
\text { counties in state }\end{array}$} & \multicolumn{3}{|c|}{ Counties with 5311 Service } & \multirow[b]{2}{*}{2011} \\
\hline & & 2008 & 2009 & 2010 & \\
\hline Alabama & 67 & 24 & 50 & 50 & 51 \\
\hline Alaska & 29 & 12 & 12 & 12 & 12 \\
\hline Arizona & 15 & 10 & 10 & 10 & 10 \\
\hline Arkansas & 75 & 42 & 42 & 42 & 42 \\
\hline California & 58 & 56 & 56 & 56 & 56 \\
\hline Colorado & 64 & 38 & 38 & 38 & 38 \\
\hline Connecticut & 8 & 8 & 8 & 8 & 8 \\
\hline Delaware & 3 & 1 & 1 & 1 & 1 \\
\hline Florida & 67 & 62 & 62 & 62 & 62 \\
\hline Georgia & 159 & 110 & 110 & 110 & 110 \\
\hline Hawaii & 4 & 3 & 3 & 3 & 3 \\
\hline Idaho & 44 & 34 & 22 & 43 & 43 \\
\hline Illinois & 102 & 64 & 64 & 73 & 78 \\
\hline Indiana & 92 & 66 & 66 & 66 & 66 \\
\hline lowa & 99 & 99 & 99 & 99 & 99 \\
\hline Kansas & 105 & 96 & 87 & 87 & 87 \\
\hline Kentucky & 120 & 89 & 89 & 103 & 103 \\
\hline Lovisiana & 64 & 31 & 31 & 32 & 32 \\
\hline Maine & 16 & 16 & 16 & 16 & 16 \\
\hline Maryland & 24 & 20 & 20 & 20 & 20 \\
\hline Massachusetts & 14 & 10 & 10 & 10 & 10 \\
\hline Michigan & 83 & 72 & 72 & 72 & 72 \\
\hline Minnesota & 87 & 73 & 73 & 73 & 73 \\
\hline Mississippi & 82 & 47 & 47 & 47 & 47 \\
\hline Missouri & 115 & 114 & 114 & 114 & 114 \\
\hline Montana & 56 & 20 & 39 & 39 & 30 \\
\hline Nebraska & 93 & 74 & 74 & 74 & 74 \\
\hline Nevada & 17 & 7 & 11 & 11 & 11 \\
\hline New Hampshire & 10 & 6 & 6 & 6 & 6 \\
\hline New Jersey & 21 & 10 & 14 & 15 & 15 \\
\hline New Mexico & 33 & 17 & 17 & 24 & 23 \\
\hline New York & 62 & 44 & 44 & 44 & 44 \\
\hline North Carolina & 100 & 75 & 80 & 97 & 97 \\
\hline North Dakota & 53 & 53 & 53 & 53 & 53 \\
\hline Ohio & 88 & 36 & 36 & 36 & 36 \\
\hline Oklahoma & 77 & 67 & 67 & 67 & 73 \\
\hline Oregon & 36 & 28 & 32 & 31 & 31 \\
\hline Pennsylvania & 67 & 26 & 27 & 29 & 29 \\
\hline Rhode Island & 5 & 2 & 2 & 2 & 2 \\
\hline South Carolina & 46 & 35 & 37 & 37 & 37 \\
\hline South Dakota & 66 & 50 & 50 & 59 & 59 \\
\hline Tennessee & 95 & 95 & 95 & 95 & 95 \\
\hline Texas & 254 & 247 & 247 & 247 & 247 \\
\hline Utah & 29 & 4 & 4 & 4 & 6 \\
\hline Vermont & 14 & 14 & 14 & 14 & 14 \\
\hline Virginia & 95 & 55 & 55 & 55 & 57 \\
\hline Washington & 39 & 24 & 24 & 24 & 36 \\
\hline West Virginia & 55 & 24 & 24 & 25 & 25 \\
\hline Wisconsin & 72 & 43 & 44 & 44 & 44 \\
\hline Wyoming & 23 & 13 & 13 & 13 & 13 \\
\hline Total & 3102 & 2266 & 2311 & 2392 & 2410 \\
\hline \multicolumn{2}{|c|}{ Percentage of counties served } & $73.0 \%$ & $74.5 \%$ & $77.1 \%$ & $77.7 \%$ \\
\hline
\end{tabular}




\section{OPERATING STATISTICS}

Total annual ridership for rural transit systems increased 1\% in 2011, from 121 million rides in 2010 to 123 million rides (see Table 13). The data suggest a decrease in ridership for both fixed-route and demandresponse service in 2011, but this could be due to how the data were reported. Data for commuter bus, demand-response taxi, and ferryboat service were reported for the first time in 2011 . It is likely that commuter bus service was previously classified as fixed-route, while demand-response taxi may have been classified as demand-response.

Table 13. Rural Transit Operating Statistics

\begin{tabular}{|c|c|c|c|c|c|}
\hline & 2008 & 2009 & 2010 & 2011 & $\begin{array}{l}\text { \% change } \\
2010-2011\end{array}$ \\
\hline & \multicolumn{5}{|c|}{------------------- millions -------------------- } \\
\hline \multicolumn{6}{|l|}{ Annual Ridership } \\
\hline Fixed-route & 64.9 & 71.4 & 76.1 & 69.2 & $-9 \%$ \\
\hline Demand-response & 43.5 & 44.0 & 43.2 & 41.2 & $-5 \%$ \\
\hline Van pool & 0.4 & 0.5 & 0.6 & 0.8 & $29 \%$ \\
\hline Commuter bus & - & - & - & 8.4 & - \\
\hline Demand-response taxi & - & - & - & 1.8 & - \\
\hline Ferryboat & - & - & - & 0.8 & - \\
\hline Other & 2.4 & 0.4 & 1.0 & 0.4 & $-58 \%$ \\
\hline Total & 111.2 & 116.4 & 120.9 & 122.6 & $1 \%$ \\
\hline \multicolumn{6}{|l|}{ Annual Vehicle Miles } \\
\hline Fixed-route & 115.3 & 114.1 & 133.8 & 125.8 & $-6 \%$ \\
\hline Demand-response & 325.5 & 357.3 & 389.3 & 376.2 & $-3 \%$ \\
\hline Van pool & 3.4 & 2.8 & 3.6 & 4.8 & $34 \%$ \\
\hline Commuter bus & - & - & - & 16.7 & - \\
\hline Demand-response taxi & - & - & - & 6.7 & - \\
\hline Ferryboat & - & - & - & 0.4 & - \\
\hline Other & 18.8 & 24.2 & 23.4 & 0.2 & $-99 \%$ \\
\hline Total & 463.0 & 498.4 & 550.1 & 530.8 & $-4 \%$ \\
\hline \multicolumn{6}{|l|}{ Annual Vehicle Hours } \\
\hline Fixed-route & 6.7 & 6.6 & 7.4 & 6.9 & $-7 \%$ \\
\hline Demand-response & 22.0 & 22.3 & 23.9 & 22.7 & $-5 \%$ \\
\hline Van pool & 0.1 & 0.0 & 0.1 & 0.3 & $226 \%$ \\
\hline Commuter bus & - & - & - & 0.7 & - \\
\hline Demand-response taxi & - & - & - & 0.9 & - \\
\hline Ferryboat & - & - & - & 0.1 & - \\
\hline Other & 0.3 & 0.7 & 0.5 & 0.0 & $-97 \%$ \\
\hline Total & 29.1 & 29.6 & 32.0 & 31.5 & $-1 \%$ \\
\hline
\end{tabular}


Changes in ridership and service provided are partly due to changes by existing agencies and partly due to the addition or subtraction of transit providers. A small difference could also be due to measurement error, or the possibility that not all agencies reported their data in a given year. To determine the degree to which ridership and service provided has changed for existing agencies, data for individual transit providers were tracked over time. The data reveal that $61 \%$ of existing providers experienced an increase in ridership from 2010 to 2011 , while $59 \%$ and $54 \%$ increased vehicle miles and hours, respectively (see Table 14). The median change from 2010 to 2011 was a $2.6 \%$ increase in vehicle miles, a $0.9 \%$ increase in vehicle hours, and a $3.8 \%$ increase in ridership. Some agencies experienced more significant gains. Forty-seven percent had an increase in ridership of $5 \%$ or more, more than a third increased ridership by $10 \%$ or more, and $22 \%$ experienced an increase of $20 \%$ or more. Some agencies also experienced significant decreases in ridership.

Table 14. Agency Level Changes in Service Miles, Hours, and Trips, 2010-2011

\begin{tabular}{lrrr}
\hline & $\begin{array}{c}\text { Vehicle } \\
\text { Miles }\end{array}$ & $\begin{array}{c}\text { Vehicle } \\
\text { Hours }\end{array}$ & Total Trips \\
\hline Median Change & $+2.6 \%$ & $+0.9 \%$ & $+3.8 \%$ \\
Percentage of Agencies with an Increase & $59 \%$ & $54 \%$ & $61 \%$ \\
Percentage of Agencies with an Increase of: & & & \\
$5 \%$ or more & $41 \%$ & $45 \%$ & $39 \%$ \\
$10 \%$ or more & $40 \%$ & $36 \%$ & $47 \%$ \\
$20 \%$ or more & $28 \%$ & $25 \%$ & $36 \%$ \\
$50 \%$ or more & $7 \%$ & $6 \%$ & $9 \%$ \\
$100 \%$ or more & $3 \%$ & $3 \%$ & $5 \%$ \\
Percentage of Agencies with an Decrease of: & & & \\
$5 \%$ or more & $27 \%$ & $30 \%$ & $28 \%$ \\
$10 \%$ or more & $18 \%$ & $22 \%$ & $20 \%$ \\
$20 \%$ or more & $9 \%$ & $14 \%$ & $12 \%$ \\
$50 \%$ or more & $2 \%$ & $4 \%$ & $4 \%$ \\
\hline
\end{tabular}

Source: Rural National Transit Database, 2010, 2011

Table 15 shows median and percentile rankings for vehicle miles and hours and passenger trips per agency in 2011 . The data show that the median vehicle miles provided per system was 184,046, the median hours of service was 11,549, and the median number of trips provided was 27,171 . For systems providing fixed-route service, the median fixed-route miles provided was 166,921, the median fixedroute hours of service was 10,377, and the median number of rides provided was 50,740. For demandresponse operations, the median values were 138,613 miles, 8,633 hours, and 17,877 rides. These median numbers changed slightly from the previous year. However, as Table 15 shows, there is significant variation in these numbers. For example, $10 \%$ of the agencies provided 853,958 or more miles of service, and the smallest $10 \%$ provided 22,606 miles or less. 
Table 15. Rural Transit Operating Statistics, Median and Percentile Rankings per Agency, 2011

\begin{tabular}{|c|c|c|c|c|c|c|c|c|c|}
\hline \multirow[b]{2}{*}{ Percentile } & \multicolumn{3}{|c|}{ Vehicle Miles } & \multicolumn{3}{|c|}{ Vehicle Hours } & \multicolumn{3}{|c|}{ Regular Unlinked Trips } \\
\hline & $\begin{array}{l}\text { Fixed- } \\
\text { Route }\end{array}$ & $\begin{array}{l}\text { Demand- } \\
\text { Response }\end{array}$ & Total & $\begin{array}{l}\text { Fixed- } \\
\text { Route }\end{array}$ & $\begin{array}{l}\text { Demand- } \\
\text { Response }\end{array}$ & Total & $\begin{array}{l}\text { Fixed- } \\
\text { Route }\end{array}$ & $\begin{array}{l}\text { Demand- } \\
\text { Response }\end{array}$ & Total \\
\hline 10th & 29,271 & 17,473 & 22,606 & 1,945 & 1,402 & 1,862 & 4,306 & 2,460 & 3,374 \\
\hline 25 th & 64,779 & 46,472 & 62,549 & 3,960 & 3,032 & 3,959 & 15,477 & 7,042 & 9,278 \\
\hline 50th & 166,921 & 138,613 & 184,046 & 10,377 & 8,633 & 11,549 & 50,740 & 17,877 & 27,171 \\
\hline 75 th & 352,034 & 344,163 & 442,632 & 20,356 & 20,827 & 26,671 & 147,856 & 41,873 & 75,557 \\
\hline 90th & 611,228 & 757,419 & 853,958 & 32,351 & 44,517 & 49,412 & 387,494 & 83,127 & 188,771 \\
\hline $\begin{array}{l}\text { Number of } \\
\text { agencies } \\
\text { reporting }\end{array}$ & 457 & 1,114 & 1,372 & 457 & 1,114 & 1,372 & 456 & 1,080 & 1,354 \\
\hline
\end{tabular}

Source: Rural National Transit Database, 2011

\section{FINANCIAL STATISTICS}

Federal funding for capital projects more than doubled in 2010 because of spending from the American Recovery and Reinvestment Act (ARRA) (see Table 16). Federal funding for capital projects dropped in 2011 but was still significantly higher than 2009 due to continued ARRA spending. Meanwhile capital funding decreased $7 \%$ from state governments and increased $21 \%$ from local sources in 2011 , following declines from both sources in 2010.

Federal support of operating costs increased $23 \%$ in 2011 , from $\$ 372$ million to $\$ 456$ million. State funding for operations increased $3 \%$ to $\$ 243$ million and local funding was unchanged at $\$ 323$ million. Total fare revenues and contract revenues were also largely unchanged from 2010 to 2011 . Meanwhile, total operating expenses increased $4 \%$.

The data in Table 16 reflect the dollar amounts reported by rural transit providers to the rural NTD, but the numbers reported could differ from the actual spending totals if any agencies did not report their data. Figure 3 shows actual federal spending levels by the FTA under the section 5311 Non-Urbanized Area Formula Program, not including ARRA funding. As shown, federal funding had been steadily increasing from 2005 through 2008, before dropping in 2009 and then increasing significantly in 2010. The figure shows a decrease in spending in 2011, but spending levels were higher than those in 2008 and 2009. 
Table 16. Rural Transit Financial Statistics: Sources of Funding

\begin{tabular}{|c|c|c|c|c|c|}
\hline & 2008 & 2009 & 2010 & 2011 & $\begin{array}{c}\text { Change } \\
2010-2011\end{array}$ \\
\hline \multicolumn{6}{|c|}{----- million dollars --------- } \\
\hline \multicolumn{6}{|l|}{ Capital Funding } \\
\hline \multicolumn{6}{|l|}{ Federal } \\
\hline 5309 & 47.4 & 49.7 & 45.8 & 41.3 & $-10 \%$ \\
\hline 5310 & 9.2 & 12.8 & 11.7 & 8.5 & $-27 \%$ \\
\hline 5311 & 68.1 & 58.7 & 47.5 & 46.6 & $-2 \%$ \\
\hline 5316 & 0.9 & 1.1 & 3.2 & 1.4 & $-55 \%$ \\
\hline 5317 & 0.1 & 2.0 & 1.2 & 1.4 & $16 \%$ \\
\hline 5320 & 1.1 & 0.0 & 0.1 & 0.2 & $95 \%$ \\
\hline Other Federal & 1.2 & 0.5 & 5.3 & 1.4 & $-74 \%$ \\
\hline ARRA & 0.0 & 34.5 & 253.6 & 152.1 & $-40 \%$ \\
\hline Total & 128.1 & 159.3 & 368.4 & 253.0 & $-31 \%$ \\
\hline State & 27.3 & 40.6 & 24.5 & 22.8 & $-7 \%$ \\
\hline Local & 32.2 & 30.1 & 19.2 & 23.3 & $21 \%$ \\
\hline \multicolumn{6}{|l|}{ Operating } \\
\hline \multicolumn{6}{|l|}{ Federal Assistance } \\
\hline 5309 & 1.8 & 5.5 & 2.1 & 3.0 & $41 \%$ \\
\hline 5310 & 7.4 & 7.6 & 10.2 & 10.4 & $1 \%$ \\
\hline 5311 & 257.1 & 279.8 & 307.3 & 370.6 & $21 \%$ \\
\hline 5316 & 9.0 & 10.1 & 12.7 & 14.8 & $16 \%$ \\
\hline 5317 & 0.3 & 1.5 & 3.6 & 5.4 & $51 \%$ \\
\hline 5320 & 0.0 & 0.2 & 0.2 & 0.1 & $-65 \%$ \\
\hline Other Federal & 17.4 & 30.6 & 24.8 & 39.4 & $59 \%$ \\
\hline ARRA & 0.0 & 3.8 & 10.7 & 12.3 & $15 \%$ \\
\hline Total & 293.0 & 339.0 & 371.7 & 455.9 & $23 \%$ \\
\hline State Assistance & 193.6 & 213.8 & 235.8 & 242.5 & $3 \%$ \\
\hline Local Assistance & 275.8 & 296.1 & 322.1 & 323.0 & $0 \%$ \\
\hline Fare Revenues & 85.7 & 97.4 & 99.9 & 99.9 & $0 \%$ \\
\hline Contract Revenues & 214.4 & 198.1 & 243.7 & 246.5 & $1 \%$ \\
\hline Total Expenses & 1063.2 & 1153.0 & 1274.2 & 1322.6 & $4 \%$ \\
\hline
\end{tabular}

Source: Rural National Transit Database, 2008-2011 


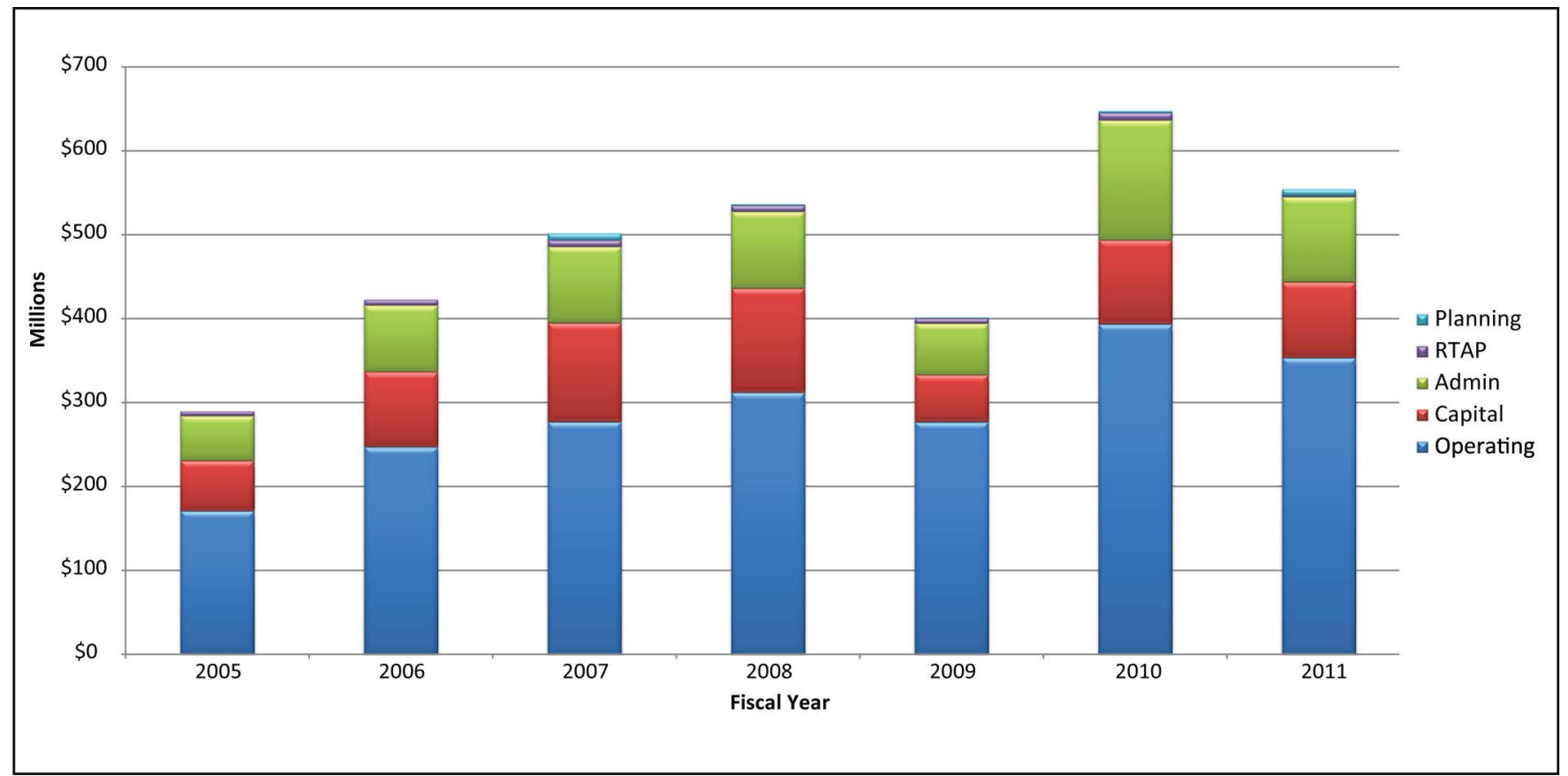

Figure 3. FTA Spending under the Section 5311 Program, 2005-2011 Source: Federal Transit Administration. Grants Data. 2013.

\section{FLEET STATISTICS}

Average fleet size rose from 15.4 to 16.5 vehicles in 2010 and then increased slightly to 16.6 vehicles in 2011 (see Table 17). Rural transit providers operated a total of 23,132 vehicles in 2011 , nearly the exact same number as the previous year (see Table 18).

The number of buses (excluding cutaways) in operation decreased $8 \%$ in 2011 , while the number of cutaways increased $3 \%$. The number of cutaways in operation has increased 50\% since 2008.
Table 17. Average Fleet Size

\begin{tabular}{lc}
\hline & Vehicles per Agency \\
\hline 2007 & 14.3 \\
2008 & 14.7 \\
2009 & 15.4 \\
2010 & 16.5 \\
2011 & 16.6
\end{tabular}

Source: Rural National Transit Database, 2007-2011

Table 18. Number of Vehicles in Operation

\begin{tabular}{lrrrr}
\hline & 2008 & 2009 & 2010 & 2011 \\
\hline Total & 19,921 & 20,890 & 23,133 & 23,132 \\
Buses & 3,930 & 3,640 & 3,904 & 3,605 \\
Cutaways & 7,230 & 8,474 & 10,621 & 10,907 \\
Vans & 5,165 & 4,927 & 4,459 & 4,350 \\
Minivans & 2,827 & 3,025 & 3,422 & 3,496 \\
Automobiles & 421 & 446 & 420 & 413 \\
School Bus & 80 & 68 & 73 & 74 \\
Over-the-road bus & 11 & 57 & 84 & 94 \\
Sports utility vehicle & 71 & 106 & 146 & 187 \\
Other & 186 & 147 & 4 & 6 \\
\hline
\end{tabular}

Source: Rural National Transit Database, 2008-2011 
Figure 4 shows the fleet composition of rural transit agencies. Cutaways comprise the largest portion (47\%) of the vehicle fleet, while vans account for $19 \%$ of the vehicles, buses $16 \%$, and minivans $15 \%$.

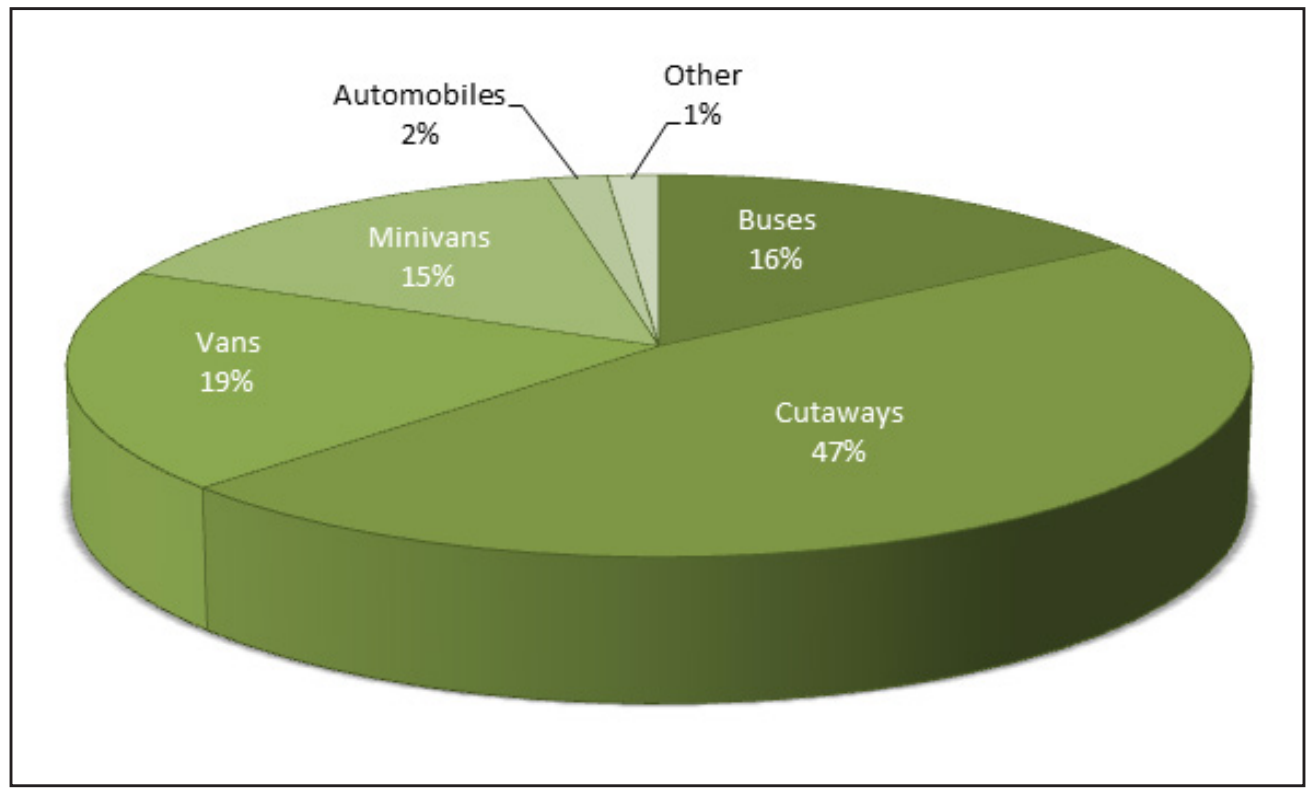

Figure 4. Fleet Composition

Eighty-two percent of these vehicles are ADA accessible (see Table 19). Most buses (95\%) and cutaways (93\%) are ADA accessible, whereas 65\% of vans and minivans were ADA accessible in 2011.

Table 19. Percentage of Rural Transit Vehicles that are ADA Accessible

\begin{tabular}{lcccc}
\hline & 2008 & 2009 & 2010 & 2011 \\
\hline \multirow{4}{*}{ Total } & ------- & Percentage & ---------- & \\
Bus & 77 & 77 & 82 & 82 \\
Cutaway & 92 & 92 & 95 & 95 \\
Van & 93 & 91 & 94 & 93 \\
Minivan & 59 & 63 & 66 & 65 \\
Automobiles & 57 & 56 & 62 & 65 \\
School Bus & 3 & 4 & 11 & 13 \\
Over-the-road bus & 36 & 22 & 15 & 30 \\
Sports utility vehicle & 64 & 79 & 85 & 82 \\
Source: Rural National Transit Database, $2008-2011$ & & & & 8 \\
\hline
\end{tabular}

The average age of the vehicles was 5.6 years in 2011 . The average vehicle length was 22.5 feet with an average seating capacity of 14.6 (see Tables 20-22). The average bus is 30.5 feet and has a seating capacity of 26.6, while the average cutaway is 23.5 feet with a seating capacity of 14.9. Average vehicle age, length, and seating capacity changed just slightly from the previous year. 
Table 20. Average Vehicle Age

\begin{tabular}{lcccc}
\hline & 2008 & 2009 & 2010 & 2011 \\
\hline Total & -----10 & 5.6 \\
Bus & 6.1 & 6.2 & 5.5 & 6.4 \\
Cutaway & 7.1 & 6.9 & 6.8 & 5.4 \\
Van & 5.8 & 5.9 & 5.1 & 5.7 \\
Minivan & 5.9 & 6.3 & 5.7 & 5.2 \\
Automobiles & 5.2 & 5.5 & 4.9 & 7.2 \\
School Bus & 7.0 & 7.4 & 6.9 & 10.9 \\
Over-the-road bus & 7.1 & 9.3 & 9.7 & 7.5 \\
Sports utility vehicle & 9.0 & 10.1 & 6.6 & 4.0 \\
\hline Source: Rural National Transit Database, 2008-2011 & 5.5 & 4.0 & 3.6 &
\end{tabular}

Table 21. Average Vehicle Length

\begin{tabular}{lcccc}
\hline & 2008 & 2009 & 2010 & 2011 \\
\hline Total & ---------- & \\
Bus & 22.4 & 22.3 & 22.6 & 22.5 \\
Cutaway & 29.3 & 29.9 & 30.6 & 30.5 \\
Van & 23.3 & 23.3 & 23.4 & 23.5 \\
Minivan & 18.8 & 19.1 & 18.9 & 19.0 \\
Automobiles & 16.7 & 16.1 & 16.2 & 16.2 \\
School Bus & 14.9 & 15.0 & 15.5 & 15.4 \\
Over-the-road bus & 32.0 & 33.6 & 34.2 & 30.8 \\
Sports utility vehicle & 35.6 & 41.4 & 43.6 & 42.3 \\
\hline
\end{tabular}

Source: Rural National Transit Database, 2008-2011

Table 22. Average Seating Capacity

\begin{tabular}{lrrrr}
\hline & 2008 & 2009 & 2010 & 2011 \\
\hline Total & 15.1 & 14.8 & 15.0 & 14.6 \\
Bus & 25.5 & 26.0 & 27.2 & 26.6 \\
Cutaway & 15.1 & 14.9 & 15.1 & 14.9 \\
Van & 12.0 & 11.4 & 10.9 & 10.8 \\
Minivan & 6.7 & 6.3 & 6.1 & 6.0 \\
Automobiles & 4.7 & 4.8 & 4.5 & 4.4 \\
School Bus & 41.1 & 45.0 & 46.5 & 40.3 \\
Over-the-road bus & 37.0 & 45.1 & 48.7 & 45.0 \\
Sports utility vehicle & - & - & 4.7 & 4.7 \\
\hline Source: Rural National Transit Database, 2008-2011 & & &
\end{tabular}


Sixty-eight percent of the vehicles are owned by the transit provider, while most of the remainder are owned by a public agency for the service provider (see Table 23). One percent of the vehicles are leased. Cutaways are most likely to be owned by the transit provider.

Table 23. Vehicle Ownership, 2011

\begin{tabular}{lccc}
\hline & $\begin{array}{c}\text { Owned by } \\
\text { provider }\end{array}$ & $\begin{array}{c}\text { Leased by } \\
\text { provider }\end{array}$ & $\begin{array}{c}\text { Owned by public } \\
\text { agency }\end{array}$ \\
\hline Total & $--1-0-0$ & 31 \\
Bus & 68 & 1 & 38 \\
Cutaway & 58 & 3 & 24 \\
Van & 75 & 1 & 44 \\
Minivan & 54 & 1 & 28 \\
Automobiles & 70 & 1 & 23 \\
School Bus & 73 & 3 & 11 \\
Over-the-road bus & 82 & 5 & 18 \\
Sports utility vehicle & 79 & 3 & 20 \\
\hline Source: Rural National Transit Database, 2011 & &
\end{tabular}

The FTA is the primary funding source for $83 \%$ of rural transit vehicles, including $84 \%$ of buses, $85 \%$ of cutaways, and $82 \%$ of vans (see Table 24). State or local sources provide the primary funding source for $13 \%$ of the vehicles.

Table 24. Primary Funding Source for Vehicles, 2011

\begin{tabular}{lcccc}
\hline & FTA & Other Federal & State or Local & Private \\
\hline \multirow{2}{*}{ Total } & - & 2 & 13 & 2 \\
Bus & 83 & 2 & 13 & 2 \\
Cutaway & 84 & 2 & 12 & 1 \\
Van & 85 & 1 & 15 & 2 \\
Minivan & 82 & 2 & 12 & 4 \\
Automobiles & 82 & 2 & 35 & 21 \\
School Bus & 41 & 9 & 66 & 8 \\
Over-the-road bus & 16 & 9 & 23 & 12 \\
Sports utility vehicle & 56 & 1 & 4 & 3 \\
\hline
\end{tabular}

Source: Rural National Transit Database, 2011 


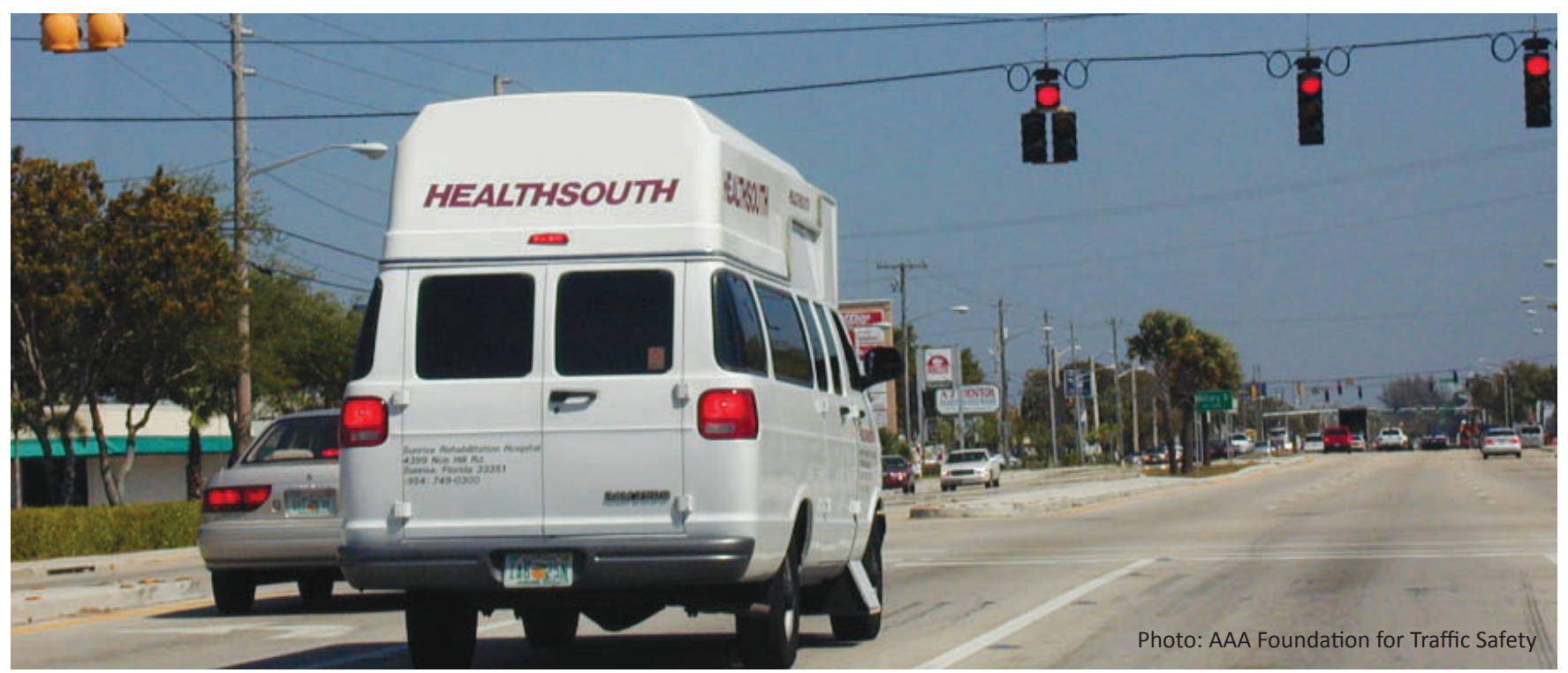

\section{NATIONAL RURAL TRANSIT PERFORMANCE MEASURES}

A few performance measures can be calculated using the data from the Rural NTD. These include two measures of service effectiveness: trips per mile and trips per hour; one measure of service efficiency: cost per mile; and one measure of cost effectiveness: cost per trip. In addition, trips per vehicle, hours of service per vehicle, and miles of service per vehicle can be measured, as well as the farebox recovery ratio.

Trips per mile increased $5 \%$ to 0.23 in 2011 . As Table 25 shows, trips per mile is significantly higher for fixedroute service (0.55) than it is for demand-response (0.11). Trips per hour increased slightly to 3.9 in 2011. The number of trips per hour was 10.0 for fixed-route service and 1.8 for demand-response.

These numbers represent the industry averages, but there is some variation between individual providers. There tends to be some variation in these measures based on the size of the operation. Table 26 groups the transit systems into six categories based on the number of vehicle miles provided. Trips per mile tends to increase with vehicle miles provided for fixed-route systems, as the larger systems provide more trips per mile, though the smallest systems are also shown to provide a higher number of trips per mile. For demand-response systems, on the other hand, trips per mile continually decreases with increases in vehicle miles. The smaller demand-response systems provide more trips per mile, possibly because they serve a smaller area with more concentrated service. 
Table 25. Trips per Mile and Trips per Hour

\begin{tabular}{|c|c|c|c|c|c|}
\hline & 2008 & 2009 & 2010 & 2011 & $\begin{array}{l}\text { \% change } \\
2010-2011\end{array}$ \\
\hline \multicolumn{6}{|l|}{ Trips per Mile } \\
\hline Fixed-route & 0.56 & 0.63 & 0.57 & 0.55 & $-3 \%$ \\
\hline Demand-response & 0.13 & 0.12 & 0.11 & 0.11 & $-1 \%$ \\
\hline Van pool & 0.13 & 0.18 & 0.17 & 0.16 & $-4 \%$ \\
\hline Commuter bus & & & & 0.50 & \\
\hline Demand-response taxi & & & & 0.27 & \\
\hline Ferryboat & & & & 1.84 & \\
\hline Total & 0.24 & 0.23 & 0.22 & 0.23 & $5 \%$ \\
\hline \multicolumn{6}{|l|}{ Trips per Hour } \\
\hline Fixed-route & 9.7 & 10.8 & 10.2 & 10.0 & $-2 \%$ \\
\hline Demand-response & 2.0 & 2.0 & 1.8 & 1.8 & $0 \%$ \\
\hline Van pool & 6.6 & 18.5 & 7.9 & 3.1 & $-60 \%$ \\
\hline Commuter bus & & & & 12.4 & \\
\hline Demand-response taxi & & & & 2.1 & \\
\hline Ferryboat & & & & 14.2 & \\
\hline Total & 3.8 & 3.9 & 3.8 & 3.9 & $3 \%$ \\
\hline
\end{tabular}

There is a similar trend for trips per hour (see Table 27). For fixed-route systems, trips per hour is the highest for the largest systems providing the greatest number of service hours, while for demand-response systems, the number of trips per hour decreases with increases in hours of service provided.

Table 26. Trips per Mile by Number of Miles Provided, 2011

\begin{tabular}{ccc}
\hline Percentile Rank & $\begin{array}{c}\text { Vehicle Miles } \\
\text { Provided }\end{array}$ & $\begin{array}{c}\text { Average Trips } \\
\text { per Mile }\end{array}$ \\
\hline Fixed-Route & $<25,482$ & \\
$1-10$ & $25,482-61,803$ & 0.54 \\
$11-25$ & $61,803-164,397$ & 0.37 \\
$26-50$ & $164,397-348,402$ & 0.40 \\
$51-75$ & $348,402-606,878$ & 0.57 \\
$76-90$ & $>606,878$ & 0.56 \\
$>90$ & & 0.66 \\
Demand-Response & $<16,397$ & \\
$1-10$ & $16,397-46,041$ & 0.50 \\
$11-25$ & $46,041-137,729$ & 0.30 \\
$26-50$ & $137,729-337,171$ & 0.25 \\
$51-75$ & $337,171-753,220$ & 0.16 \\
$76-90$ & $>753,220$ & 0.11 \\
$>90$ & & 0.10 \\
\hline
\end{tabular}

Source: Rural National Transit Database, 2011 
Table 27. Trips per Hour by Number of Hours Provided, 2011

\begin{tabular}{ccc}
\hline Percentile Rank & $\begin{array}{c}\text { Vehicle Hours } \\
\text { Provided }\end{array}$ & $\begin{array}{c}\text { Average Trips } \\
\text { per Hour }\end{array}$ \\
\hline Fixed-Route & $<1,804$ & \\
$1-10$ & $1,804-3,829$ & 6.7 \\
$11-25$ & $3,829-10,043$ & 4.9 \\
$26-50$ & $10,043-20,240$ & 6.1 \\
$51-75$ & $20,240-32,181$ & 7.7 \\
$76-90$ & $>32,181$ & 10.2 \\
$>90$ & & 13.0 \\
Demand-Response & $<1,353$ & \\
$1-10$ & $1,353-2,946$ & 4.0 \\
$11-25$ & $2,946-8,525$ & 4.2 \\
$26-50$ & $8,525-20,495$ & 3.2 \\
$51-75$ & $20,495-44,389$ & 2.6 \\
$76-90$ & $>44,389$ & 1.8 \\
$>90$ & & 1.7 \\
\hline Source: Rural National Transit Database, 2011 &
\end{tabular}

Source: Rural National Transit Database, 2011

Trips per vehicle increased 1\% in 2011 to 5,301. Meanwhile, rural transit vehicles averaged 22,947 miles and 1,364 hours of service in 2011, small decreases from 2010 (see Table 28).

Operating cost per trip was $\$ 10.78$ in 2011 , a $2 \%$ increase from the previous year. The costs were significantly higher for demand-response service. The rural NTD does not report cost data by mode, so it is not possible to compute average fixed-route and demand-response costs. However, many providers offer just one type of service, so averages can be calculated for those systems that offer just demand-response or just fixed-route service. In 2011, 816 such systems operated just demand-response service, and 192 offered just fixed-route service. Their average costs are shown in Table 29. The average operating cost for fixed-route-only systems increased $2 \%$ to $\$ 6.96$ per trip in 2011 , while that for demandresponse-only systems increased to $\$ 17.31$ per trip. Operating cost per mile in 2011 was $\$ 2.83$ for fixedroute-only systems, $\$ 2.06$ for demand-response-only systems, and $\$ 2.49$ per mile overall. Costs tend to be higher per mile for the fixed-route operators but lower per trip due to the greater number of rides provided.

Fare revenues in 2011 covered $8 \%$ of the operating costs. The farebox recovery ratio has been unchanged since 2007 and is just slightly higher for fixed-route systems.

Table 28. Trips, Miles, and Hours per Vehicle

\begin{tabular}{lrrrrc}
\hline & & & & \multicolumn{1}{c}{$\%$ change } \\
& 2008 & 2009 & 2010 & 2011 & $2010-11$ \\
\hline Trips per Vehicle & 5,580 & 5,572 & 5,227 & 5,301 & $1 \%$ \\
Miles per Vehicle & 23,243 & 23,857 & 23,778 & 22,947 & $-3 \%$ \\
Hours per Vehicle & 1,462 & 1,418 & 1,383 & 1,364 & $-1 \%$ \\
\hline Source: Rural National Transit Database, 2008-2011 & & &
\end{tabular}


Table 29. Operating Costs per Trip and per Mile and Farebox Recovery Ratio

\begin{tabular}{lrrrrr}
\hline & 2008 & 2009 & 2010 & 2011 & $\begin{array}{c}\text { \% change } \\
2010-11\end{array}$ \\
\hline Operating Expense per Trip & & & & & \\
$\quad$ Total & 9.57 & 9.91 & 10.54 & 10.78 & $2 \%$ \\
$\quad$ Fixed-route-only & 6.13 & 5.96 & 6.80 & 6.96 & $2 \%$ \\
$\quad$ Demand-response-only & 14.62 & 15.18 & 16.83 & 17.31 & $3 \%$ \\
Operating Expense per Mile & & & & & \\
$\quad$ Total & 2.30 & 2.31 & 2.32 & 2.49 & $8 \%$ \\
$\quad$ Fixed-route-only & 3.05 & 3.06 & 2.93 & 2.83 & $-4 \%$ \\
$\quad$ Demand-response-only & 1.99 & 2.01 & 2.02 & 2.06 & $2 \%$ \\
Farebox Recovery Ratio & & & & & \\
$\quad \begin{array}{l}\text { Total } \\
\text { Fixed-route-only }\end{array}$ & 0.08 & 0.08 & 0.08 & 0.08 & $-4 \%$ \\
$\quad$ Demand-response-only & 0.09 & 0.09 & 0.08 & 0.08 & $0 \%$ \\
\hline
\end{tabular}

Source: Rural National Transit Database, 2008-2011

While Table 29 shows overall averages, there is significant variation in costs between transit agencies across the country. Table 30 shows percentile rankings for operating costs per trip and per mile and for farebox recovery ratio, including both demand-response and fixed-route service. (The percentile rank is the percentage of transit operators with results at or below the reported number. For example, $10 \%$ of transit operators have an operating epense per trip at or below $\$ 5.35$, while $50 \%$ have an operating expense per trip at or below $\$ 13.82$, and $90 \%$ are at or below $\$ 54.29$.)

Table 30. Operating Costs per Trip and per Mile and Farebox Recovery Ratio, Percentile Rankings, 2011

\begin{tabular}{|c|c|c|c|}
\hline \multirow[b]{2}{*}{ Percentile Rank } & \multicolumn{2}{|c|}{ Operating Expense } & \multirow{2}{*}{$\begin{array}{c}\text { Farebox } \\
\text { Recovery Ratio }\end{array}$} \\
\hline & Per Trip & Per Mile & \\
\hline \multicolumn{4}{|l|}{ Total } \\
\hline $10^{\text {th }}$ & 5.35 & 1.30 & 0.02 \\
\hline $20^{\text {th }}$ & 8.40 & 1.80 & 0.04 \\
\hline $50^{\text {th }}$ & 13.82 & 2.56 & 0.07 \\
\hline $75^{\text {th }}$ & 25.07 & 3.65 & 0.12 \\
\hline $90^{\text {th }}$ & 54.29 & 5.14 & 0.20 \\
\hline \multicolumn{4}{|l|}{ Fixed-route-only } \\
\hline $10^{\text {th }}$ & 3.75 & 1.50 & 0.01 \\
\hline $20^{\text {th }}$ & 6.49 & 2.11 & 0.03 \\
\hline $50^{\text {th }}$ & 11.43 & 3.01 & 0.07 \\
\hline $75^{\text {th }}$ & 19.02 & 4.09 & 0.12 \\
\hline $90^{\text {th }}$ & 30.89 & 5.80 & 0.18 \\
\hline \multicolumn{4}{|l|}{ Demand-reponse-only } \\
\hline $10^{\text {th }}$ & 5.80 & 1.18 & 0.02 \\
\hline $20^{\text {th }}$ & 9.27 & 1.64 & 0.04 \\
\hline $50^{\text {th }}$ & 15.55 & 2.31 & 0.08 \\
\hline $75^{\text {th }}$ & 30.08 & 3.29 & 0.12 \\
\hline $90^{\text {th }}$ & 60.33 & 4.67 & 0.18 \\
\hline
\end{tabular}


Some of the variations could be explained by the size of the operations. Table 31 categorizes transit agencies based on the number of vehicle miles provided. The operating expense per mile is lower for the larger systems, but expense per trip does not appear to be influenced by the number of miles provided, as the larger demand-response systems tend to have fewer trips per mile of service.

Table 31. Operating Statistics and Performance Measures by Size of Operation, 2011

\begin{tabular}{|c|c|c|c|c|c|c|c|c|c|c|}
\hline \multirow[b]{2}{*}{$\begin{array}{c}\text { Size of } \\
\text { Agency* }\end{array}$} & \multirow{2}{*}{$\begin{array}{l}\text { Number } \\
\text { of } \\
\text { Agencies }\end{array}$} & \multicolumn{2}{|c|}{$\begin{array}{c}\text { Vehicle } \\
\text { Miles }\end{array}$} & \multirow[b]{2}{*}{$\begin{array}{l}\text { Total } \\
\text { Miles }\end{array}$} & \multirow[b]{2}{*}{$\begin{array}{l}\text { Total } \\
\text { Trips }\end{array}$} & \multirow[b]{2}{*}{$\begin{array}{c}\text { Fare } \\
\text { revenues }\end{array}$} & \multirow[b]{2}{*}{$\begin{array}{l}\text { Operating } \\
\text { expenses }\end{array}$} & \multicolumn{2}{|c|}{$\begin{array}{l}\text { Operating } \\
\text { Expense }\end{array}$} & \multirow{2}{*}{$\begin{array}{c}\text { Farebox } \\
\text { recovery } \\
\text { ratio }\end{array}$} \\
\hline & & Min & Max & & & & & Per Trip & Per Mile & \\
\hline & & & & 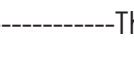 & ousands- & 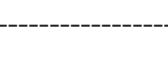 & --------- & & & \\
\hline Very small & 137 & 0 & 23 & 1,662 & 676 & 963 & 8,134 & 12.05 & 4.89 & 0.12 \\
\hline Small & 206 & 23 & 63 & 8,556 & 2,506 & 2,373 & 28,928 & 11.54 & 3.38 & 0.08 \\
\hline Medium-small & 343 & 63 & 184 & 39,788 & 11,153 & 9,822 & 115,134 & 10.32 & 2.89 & 0.09 \\
\hline Medium-large & 343 & 184 & 443 & 98,215 & 28,461 & 38,009 & 270,185 & 9.49 & 2.75 & 0.14 \\
\hline Large & 206 & 443 & 854 & 124,549 & 36,364 & 27,649 & 330,854 & 9.10 & 2.66 & 0.08 \\
\hline Very large & 137 & 854 & 0 & 258,041 & 43,420 & 33,375 & 566,625 & 13.05 & 2.20 & 0.06 \\
\hline
\end{tabular}

*Agency size is determined by vehicle miles of service provided using the following categorization: smallest $10 \%$ is very small, $10^{\text {th }}$ to $25^{\text {th }}$ percentile is small, $25^{\text {th }}$ to $50^{\text {th }}$ percentile is medium-small, $50^{\text {th }}$ to $75^{\text {th }}$ percentile is medium-large, $75^{\text {th }}$ to $90^{\text {th }}$ percentile is large, and largest $10 \%$ is very large.

Source: Rural National Transit Database, 2011 


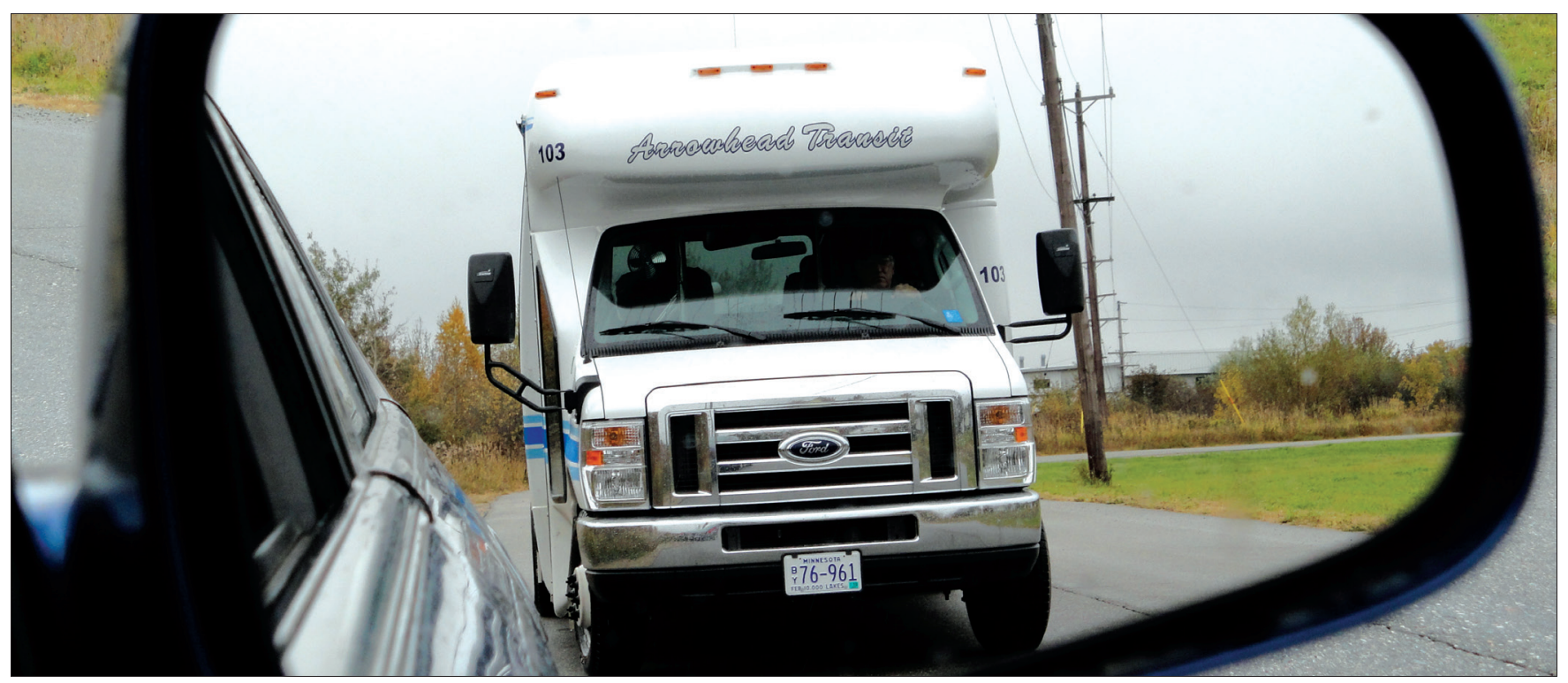

\section{REGIONAL AND STATE STATISTICS}

The data described in the previous sections are aggregate national data, but there may be some regional differences. Therefore, data in this section are presented at the regional and state levels. The regions used are based on the FTA's regional classification. The FTA divides the country into 10 regions, as shown in Figure 5. Table 32 shows how rural transit statistics vary between those regions.

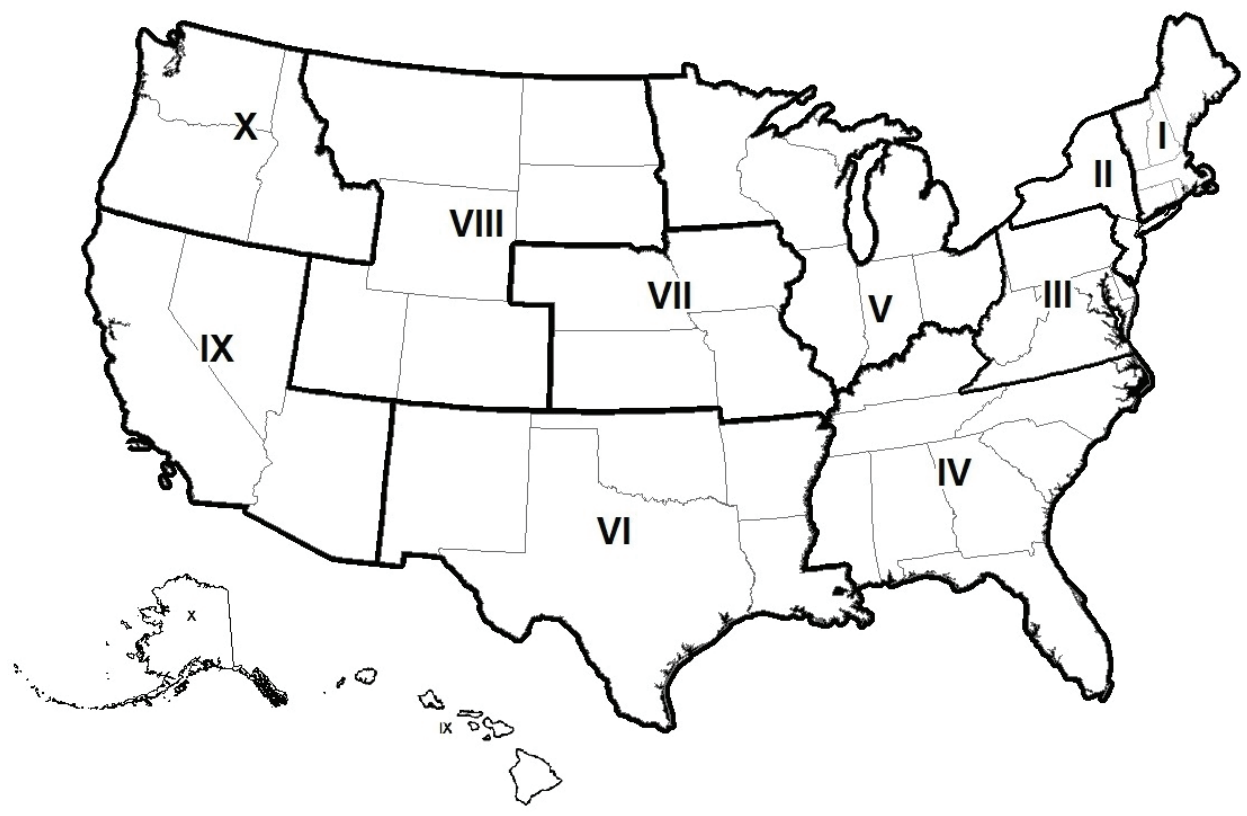

Figure 5. FTA Regions

The greatest number of rural transit agencies is in regions 4, 5, and 7, followed by regions 8 and 6 . The operators in these regions are mostly demand-response providers. The northeast and far western regions have a greater orientation toward fixed-route service. 
Annual ridership in 2011 was highest in regions 5 (19.2 million rides) and 8 (17.9 million rides). Region 4 provided the highest level of service, by a significant margin, with 154 million vehicle miles and 9.1 million vehicle hours of service, most of it being demand-response. Region 4 also had the greatest number of vehicles in service, many of them being vans.

Trips per mile and per hour were highest in region 8, according to the data, and regions 8 and 9 provided the most rides per vehicle.

Operating cost per trip was the highest in region 4. For the fixed-route-only agencies, cost per trip was highest in region 2 at $\$ 10.54$ and lowest in region 7 at $\$ 4.31$. The lowest cost for demand-response-only providers was $\$ 9.54$ per trip in region 7.

State-level statistics are shown in Tables 33-37.

Table 32. Regional Data, 2011

\begin{tabular}{|c|c|c|c|c|c|c|c|c|c|c|}
\hline & \multicolumn{10}{|c|}{ FTA Region } \\
\hline & 1 & 2 & 3 & 4 & 5 & 6 & 7 & 8 & 9 & 10 \\
\hline \multicolumn{11}{|l|}{ Number of Agencies } \\
\hline Fixed-route & 29 & 51 & 51 & 63 & 45 & 33 & 14 & 42 & 69 & 67 \\
\hline Demand-response & 30 & 9 & 31 & 251 & 232 & 109 & 189 & 114 & 74 & 82 \\
\hline Total & 36 & 57 & 58 & 279 & 287 & 117 & 197 & 140 & 106 & 115 \\
\hline Counties Served & $84 \%$ & $71 \%$ & $54 \%$ & $82 \%$ & $70 \%$ & $83 \%$ & $91 \%$ & $68 \%$ & $85 \%$ & $82 \%$ \\
\hline \multicolumn{11}{|c|}{ Annual Ridership (million rides) } \\
\hline Fixed-route & 4.8 & 4.3 & 10.5 & 7.3 & 3.4 & 2.7 & 1.9 & 12.2 & 10.2 & 11.8 \\
\hline Demand-response & 0.6 & 0.6 & 1.2 & 6.3 & 11.2 & 5.6 & 8.0 & 3.6 & 2.1 & 1.8 \\
\hline Total & 5.8 & 5.0 & 11.9 & 14.1 & 19.2 & 8.5 & 10.3 & 17.9 & 14.8 & 15.0 \\
\hline \multicolumn{11}{|c|}{ Annual Vehicle Miles (million miles) } \\
\hline Fixed-route & 8.0 & 14.6 & 21.0 & 18.6 & 7.8 & 6.6 & 3.0 & 10.7 & 17.9 & 17.5 \\
\hline Demand-response & 17.6 & 6.3 & 12.7 & 133.5 & 74.0 & 53.7 & 44.5 & 13.7 & 8.3 & 11.8 \\
\hline Total & 28.2 & 21.3 & 34.3 & 154.1 & 88.8 & 61.8 & 47.7 & 27.4 & 32.7 & 34.5 \\
\hline \multicolumn{11}{|c|}{ Annual Vehicle Hours (million hours) } \\
\hline Fixed-route & 0.4 & 0.8 & 1.1 & 1.0 & 0.5 & 0.4 & 0.2 & 0.7 & 1.0 & 0.8 \\
\hline Demand-response & 0.7 & 0.4 & 0.7 & 8.0 & 4.6 & 3.4 & 2.6 & 1.1 & 0.6 & 0.7 \\
\hline Total & 1.4 & 1.2 & 1.8 & 9.1 & 5.7 & 3.8 & 2.8 & 1.9 & 1.9 & 1.9 \\
\hline \multicolumn{11}{|l|}{ Number of Vehicles } \\
\hline Total & 755 & 829 & 1,527 & 5,875 & 4,075 & 3,251 & 2,340 & 1,611 & 1,332 & 1,537 \\
\hline Bus & 244 & 345 & 409 & 617 & 662 & 101 & 109 & 387 & 419 & 312 \\
\hline Cutaway & 406 & 428 & 828 & 2,182 & 1,833 & 1,780 & 1,416 & 626 & 682 & 726 \\
\hline Van & 58 & 19 & 126 & 2,228 & 720 & 435 & 314 & 145 & 53 & 252 \\
\hline Minivan & 40 & 7 & 94 & 683 & 667 & 851 & 473 & 382 & 97 & 202 \\
\hline Other & 4 & 30 & 70 & 165 & 193 & 84 & 28 & 71 & 81 & 43 \\
\hline Vehicles ADA Accessible & $91 \%$ & $95 \%$ & $93 \%$ & $73 \%$ & $87 \%$ & $81 \%$ & $82 \%$ & $75 \%$ & $89 \%$ & $78 \%$ \\
\hline
\end{tabular}


Table 32. Regional Data, 2011 (continued)

\begin{tabular}{|c|c|c|c|c|c|c|c|c|c|c|}
\hline & \multicolumn{10}{|c|}{ FTA Region } \\
\hline & 1 & 2 & 3 & 4 & 5 & 6 & 7 & 8 & 9 & 10 \\
\hline Average Vehicle Age & 5.7 & 5.3 & 5.3 & 4.7 & 5.4 & 5.8 & 6.1 & 7.2 & 6.3 & 6.7 \\
\hline Average Vehicle Length & 25.6 & 25.0 & 23.8 & 20.8 & 22.2 & 21.0 & 22.1 & 24.3 & 26.7 & 24.0 \\
\hline $\begin{array}{l}\text { Average Vehicle } \\
\text { Capacity }\end{array}$ & 19.1 & 16.9 & 17.1 & 12.5 & 13.5 & 12.3 & 13.1 & 17.5 & 21.8 & 17.4 \\
\hline \multicolumn{11}{|l|}{ Trips Per Mile } \\
\hline Total & 0.21 & 0.24 & 0.35 & 0.09 & 0.22 & 0.14 & 0.22 & 0.65 & 0.45 & 0.44 \\
\hline Fixed-route & 0.60 & 0.30 & 0.50 & 0.39 & 0.44 & 0.41 & 0.63 & 1.14 & 0.57 & 0.68 \\
\hline Demand-response & 0.03 & 0.10 & 0.10 & 0.05 & 0.15 & 0.10 & 0.18 & 0.26 & 0.25 & 0.15 \\
\hline \multicolumn{11}{|l|}{ Trips Per Hour } \\
\hline Total & 4.0 & 4.1 & 6.5 & 1.6 & 3.4 & 2.2 & 3.7 & 9.3 & 7.9 & 7.9 \\
\hline Fixed-route & 11.5 & 5.3 & 9.4 & 7.3 & 7.6 & 7.2 & 9.0 & 18.6 & 10.0 & 14.0 \\
\hline Demand-response & 0.9 & 1.6 & 1.9 & 0.8 & 2.4 & 1.7 & 3.1 & 3.2 & 3.4 & 2.5 \\
\hline Trips Per Vehicle & 7,686 & 6,061 & 7,792 & 2,408 & 4,715 & 2,608 & 4,406 & 11,106 & 11,139 & 9,778 \\
\hline Miles Per Vehicle & 37,324 & 25,724 & 22,493 & 26,226 & 21,794 & 19,014 & 20,377 & 16,978 & 24,536 & 22,472 \\
\hline Hours Per Vehicle & 1,915 & 1,494 & 1,193 & 1,545 & 1,389 & 1,168 & 1,196 & 1,198 & 1,413 & 1,235 \\
\hline \multicolumn{11}{|l|}{ Operating Expense Per Trip } \\
\hline Total & 14.37 & 12.67 & 8.24 & 19.42 & 12.17 & 15.79 & 8.34 & 5.79 & 8.54 & 7.91 \\
\hline Fixed-route only & 10.22 & 10.54 & 8.82 & 5.28 & 6.78 & 9.22 & 4.31 & 4.69 & 8.08 & 6.28 \\
\hline $\begin{array}{l}\text { Demand-response- } \\
\text { only }\end{array}$ & 15.97 & 23.09 & 13.32 & 32.51 & 17.71 & 18.63 & 9.54 & 9.68 & 21.20 & 18.05 \\
\hline \multicolumn{11}{|l|}{ Operating Expense Per Mile } \\
\hline Total & 2.96 & 2.99 & 2.85 & 1.78 & 2.63 & 2.17 & 1.80 & 3.79 & 3.88 & 3.44 \\
\hline Fixed-route-only & 0.95 & 3.04 & 2.33 & 1.73 & 3.06 & 1.94 & 3.39 & 4.75 & 3.80 & 4.31 \\
\hline $\begin{array}{l}\text { Demand-response- } \\
\text { only }\end{array}$ & 3.89 & 5.07 & 1.70 & 1.70 & 2.54 & 2.06 & 1.71 & 2.51 & 5.48 & 2.61 \\
\hline Farebox Recovery Ratio & 0.05 & 0.06 & 0.09 & 0.05 & 0.09 & 0.05 & 0.08 & 0.10 & 0.10 & 0.10 \\
\hline
\end{tabular}

Source: Rural National Transit Database, 2011 
Table 33. Rural Transit Vehicle Revenue Miles of Service by State, 2008-201 1 (million miles)

\begin{tabular}{|c|c|c|c|c|c|c|c|c|c|c|c|c|c|c|c|c|}
\hline & \multicolumn{4}{|c|}{ Total } & \multicolumn{4}{|c|}{ Fixed-Route Service } & \multicolumn{4}{|c|}{ Demand-Response Service } & \multicolumn{4}{|c|}{ Other Service } \\
\hline & 2008 & 2009 & 2010 & 2011 & 2008 & 2009 & 2010 & 2011 & 2008 & 2009 & 2010 & 2011 & 2008 & 2009 & 2010 & 2011 \\
\hline Alabama & 6.3 & 6.3 & 5.9 & 5.3 & .0 & .0 & .0 & .0 & 6.3 & 6.3 & 5.9 & 5.3 & .0 & .0 & .0 & .0 \\
\hline Alaska & 2.2 & 2.3 & 1.8 & 2.7 & 1.1 & 1.2 & 1.3 & 1.4 & 1.1 & 1.1 & .5 & .8 & .0 & .0 & .0 & .5 \\
\hline Arizona & 2.7 & 2.8 & 3.2 & 3.7 & 2.2 & 2.3 & 2.8 & 2.6 & .5 & .5 & .4 & 6 & .0 & .0 & .0 & 6 \\
\hline Arkansas & 7.3 & 7.7 & 8.1 & 8.1 & .2 & .0 & .0 & .2 & 7.2 & 7.7 & 8.1 & 7.9 & .0 & .0 & .0 & .0 \\
\hline California & 18.8 & 17.8 & 20.0 & 18.5 & 13.1 & 13.2 & 15.2 & 9.8 & 4.4 & 4.6 & 4.8 & 4.8 & 1.2 & .0 & .0 & 3.9 \\
\hline Colorado & 10.7 & 10.2 & 11.0 & 10.7 & 9.9 & 8.7 & 8.3 & 5.7 & .8 & 1.5 & 2.7 & 2.5 & .1 & .1 & .0 & 2.4 \\
\hline Connecticut & 1.4 & 1.5 & 1.5 & 1.6 & .6 & .5 & .7 & .7 & .8 & 1.0 & .7 & .8 & .0 & .0 & .0 & .1 \\
\hline Delaware & .0 & .0 & .0 & .0 & .0 & .0 & .0 & .0 & .0 & .0 & .0 & .0 & .0 & .0 & .0 & .0 \\
\hline Florida & 14.5 & 13.7 & 14.5 & 17.2 & 2.0 & 2.8 & 3.0 & 5.2 & 11.4 & 10.9 & 11.4 & 11.8 & 1.1 & .1 & .0 & .2 \\
\hline Georgia & 13.0 & 13.0 & 15.1 & 16.3 & .0 & .0 & .0 & .0 & 13.0 & 13.0 & 15.1 & 16.3 & .0 & .0 & .0 & .0 \\
\hline Hawaii & 4.2 & 5.0 & 5.0 & 7.0 & 4.2 & 4.9 & 5.0 & 3.3 & .0 & .1 & .0 & 1.7 & .0 & .0 & .0 & 2.1 \\
\hline Idaho & 1.9 & 1.7 & 2.8 & 2.7 & .9 & .9 & 1.9 & 1.8 & .8 & .5 & .7 & .7 & .2 & .2 & .0 & .2 \\
\hline Illinois & 9.4 & 11.1 & 12.8 & 15.0 & .9 & 1.0 & 1.0 & .0 & 8.5 & 10.1 & 11.7 & 13.7 & .0 & .0 & .0 & 1.4 \\
\hline Indiana & 12.6 & 13.1 & 14.9 & 15.0 & .3 & .5 & .8 & .7 & 12.3 & 12.7 & 14.1 & 14.3 & .0 & .0 & .0 & .0 \\
\hline lowa & 15.5 & 15.3 & 15.1 & 14.7 & .0 & .0 & .0 & 2.0 & 15.5 & 15.3 & 15.1 & 12.7 & .0 & .0 & .0 & .0 \\
\hline Kansas & 6.8 & 6.2 & 6.3 & 6.9 & .5 & .4 & .6 & .8 & 6.3 & 5.8 & 5.7 & 6.1 & .0 & .0 & .0 & .0 \\
\hline Kentucky & 24.6 & 25.4 & 30.4 & 27.2 & 2.3 & 1.5 & .8 & .6 & 22.3 & 23.9 & 29.6 & 26.6 & .0 & .0 & .0 & .0 \\
\hline Louisiana & 6.1 & 5.7 & 5.9 & 6.0 & .7 & .0 & .0 & .1 & 5.4 & 5.7 & 5.9 & 6.0 & .0 & .0 & .0 & .0 \\
\hline Maine & 23.0 & 42.5 & 41.3 & 14.1 & 1.5 & 2.6 & 1.0 & 2.8 & 9.1 & 18.7 & 17.1 & 10.1 & 12.4 & 21.2 & 23.2 & 1.2 \\
\hline Maryland & 4.8 & 5.3 & 9.4 & 7.0 & 2.8 & 3.2 & 5.4 & 4.2 & 1.9 & 2.1 & 3.9 & 2.6 & .0 & .0 & .0 & .2 \\
\hline Massachusetts & 2.0 & 1.9 & 2.0 & 2.2 & 1.3 & 1.4 & 1.6 & 1.7 & .6 & .5 & .4 & .5 & .0 & .0 & .0 & .0 \\
\hline Michigan & 22.9 & 22.7 & 23.8 & 23.7 & 1.9 & .0 & .0 & .0 & 21.0 & 22.7 & 23.8 & 23.7 & .0 & .0 & .0 & .0 \\
\hline Minnesota & 9.9 & 12.1 & 12.6 & 13.9 & 3.3 & 3.2 & 3.0 & 3.7 & 6.6 & 8.9 & 9.6 & 10.2 & .0 & .0 & .0 & .0 \\
\hline Mississippi & 7.9 & 8.5 & 8.6 & 8.1 & 7.9 & 1.2 & 8.6 & 8.1 & .0 & 7.3 & .0 & .0 & .0 & .0 & .0 & .0 \\
\hline Missouri & 18.6 & 23.2 & 23.4 & 23.0 & .1 & .6 & .0 & .0 & 18.5 & 22.6 & 23.2 & 22.8 & .0 & .0 & .2 & .2 \\
\hline Montana & 2.7 & 2.9 & 3.3 & 3.4 & 1.2 & 1.4 & 1.3 & 1.4 & 1.3 & 1.4 & 1.8 & 1.5 & .3 & .2 & .0 & .4 \\
\hline Nebraska & 2.4 & 2.5 & 2.5 & 2.6 & .0 & .0 & .0 & .0 & 2.4 & 2.5 & 2.5 & 2.6 & .0 & .0 & .0 & .0 \\
\hline Nevada & .6 & 1.5 & 1.6 & 1.4 & .5 & 1.0 & .9 & .9 & .0 & .6 & .7 & .5 & .0 & .0 & .0 & .0 \\
\hline New Hampshire & 1.0 & 1.3 & 1.4 & 1.4 & .9 & 1.0 & 1.0 & 1.0 & .2 & .3 & .4 & .4 & .0 & .0 & .0 & .0 \\
\hline New Jersey & 9.4 & .1 & 7.3 & 7.5 & 1.4 & .0 & 1.4 & 1.2 & 8.0 & .0 & 5.9 & 6.3 & .0 & .0 & .0 & .0 \\
\hline New Mexico & 3.6 & 4.4 & 6.2 & 5.0 & 1.9 & 2.2 & 4.5 & 3.0 & 1.6 & 2.2 & 1.8 & 1.5 & .0 & .0 & .0 & .5 \\
\hline New York & 13.3 & 13.4 & 13.7 & 13.8 & 13.3 & 13.4 & 13.7 & 13.4 & .0 & .0 & .0 & .0 & .0 & .0 & .0 & .4 \\
\hline North Carolina & 28.5 & 33.1 & 44.4 & 41.4 & .4 & 2.9 & 3.2 & 1.6 & 28.0 & 30.3 & 41.2 & 39.9 & .0 & .0 & .0 & .0 \\
\hline North Dakota & 2.5 & 2.6 & 2.9 & 3.1 & .9 & .2 & .2 & .0 & 1.6 & 2.4 & 2.7 & 3.0 & .0 & .0 & .0 & .1 \\
\hline Ohio & 10.1 & 10.4 & 10.9 & 11.2 & .5 & .5 & .7 & .6 & 9.6 & 9.9 & 10.2 & 10.6 & .0 & .0 & .0 & .0 \\
\hline Oklahoma & 16.0 & 16.5 & 17.1 & 18.7 & .8 & 1.1 & 1.4 & 1.1 & 15.2 & 15.4 & 15.7 & 17.6 & .0 & .0 & .0 & .0 \\
\hline Oregon & 6.6 & 7.6 & 8.8 & 9.6 & 4.3 & 4.4 & 5.0 & 4.4 & 2.2 & 3.2 & 3.8 & 4.4 & .0 & .0 & .0 & .8 \\
\hline Pennsylvania & 9.1 & 9.2 & 13.2 & 11.8 & 4.2 & 4.6 & 4.9 & 4.4 & 4.9 & 4.5 & 8.3 & 7.0 & .0 & .0 & .0 & .4 \\
\hline Rhode Island & .0 & .0 & .0 & .0 & .0 & .0 & .0 & .0 & .0 & .0 & .0 & .0 & .0 & .0 & .0 & .0 \\
\hline South Carolina & 7.3 & 7.8 & 7.4 & 7.5 & 2.2 & 2.3 & 2.3 & 1.2 & 1.7 & 2.6 & 5.1 & 5.2 & 3.3 & 2.9 & .0 & 1.1 \\
\hline South Dakota & 3.9 & 4.1 & 4.0 & 4.2 & .0 & .0 & .0 & .0 & 3.9 & 4.1 & 4.0 & 4.2 & .0 & .0 & .0 & .0 \\
\hline Tennessee & 23.5 & 24.6 & 26.3 & 29.4 & .0 & 1.0 & 1.3 & 1.0 & 22.4 & 23.6 & 25.0 & 27.7 & 1.0 & .0 & .0 & .6 \\
\hline Texas & 19.2 & 20.6 & 21.2 & 21.4 & .0 & .0 & .0 & 1.4 & 19.2 & 20.6 & 21.2 & 19.1 & .0 & .0 & .0 & .8 \\
\hline Utah & 1.1 & 1.3 & 1.3 & 1.3 & 1.1 & 1.2 & 1.2 & 1.2 & .1 & .1 & .1 & .1 & .0 & .0 & .0 & .0 \\
\hline Vermont & 12.5 & 11.6 & 11.6 & 8.8 & 2.6 & 2.5 & 2.8 & 1.8 & 9.8 & 9.1 & 8.8 & 5.7 & .0 & .0 & .0 & 1.2 \\
\hline Virginia & 8.0 & 8.2 & 8.5 & 11.4 & 4.9 & 5.3 & 5.4 & 8.2 & 3.1 & 2.8 & 3.1 & 3.1 & .0 & .0 & .0 & .0 \\
\hline Washington & 16.0 & 15.7 & 16.0 & 16.9 & 7.8 & 7.9 & 8.6 & 8.0 & 5.9 & 5.7 & 4.7 & 5.4 & 2.3 & 2.2 & .0 & 3.5 \\
\hline West Virginia & 4.0 & 4.1 & 4.1 & 4.2 & 3.5 & 4.1 & 4.1 & 4.2 & .5 & .0 & .0 & .0 & .0 & .0 & .0 & .0 \\
\hline Wisconsin & 6.9 & 7.2 & 7.5 & 8.3 & 1.4 & 1.5 & 2.4 & 2.8 & 5.5 & 5.7 & 5.1 & .6 & .0 & .0 & .0 & 5.0 \\
\hline Wyoming & 3.0 & 3.2 & 2.4 & 2.4 & 1.4 & 1.3 & 1.4 & 1.2 & 1.6 & 2.0 & 1.0 & 1.2 & .0 & .0 & .0 & .0 \\
\hline
\end{tabular}


Table 34. State Operating Statistics, 2011

\begin{tabular}{|c|c|c|c|c|c|c|c|c|c|c|c|}
\hline & \multirow{2}{*}{$\begin{array}{c}\text { Number } \\
\text { of } \\
\text { Agencies }\end{array}$} & \multirow{2}{*}{$\begin{array}{c}\text { Counties } \\
\text { Served } \\
(\%)\end{array}$} & \multicolumn{3}{|c|}{ Annual Ridership } & \multicolumn{3}{|c|}{ Annual Vehicle Miles } & \multicolumn{3}{|c|}{ Annual Vehicle Hours } \\
\hline & & & Total & $\begin{array}{l}\text { Fixed- } \\
\text { Route }\end{array}$ & $\begin{array}{l}\text { Demand- } \\
\text { Response }\end{array}$ & Total & $\begin{array}{l}\text { Fixed- } \\
\text { Route }\end{array}$ & $\begin{array}{l}\text { Demand- } \\
\text { Response }\end{array}$ & Total & $\begin{array}{l}\text { Fixed- } \\
\text { Route }\end{array}$ & $\begin{array}{l}\text { Demand- } \\
\text { Response }\end{array}$ \\
\hline & & & -------thc & usand ride & es-------- & -------th & usand mil & les--------- & --------thc & usand hou & urs--------- \\
\hline Alabama & 51 & $76 \%$ & 1,008 & 0 & 1,008 & 5,318 & 0 & 5,318 & 342 & 0 & 342 \\
\hline Alaska & 12 & $41 \%$ & 1,879 & 1,662 & 106 & 2,662 & 1,364 & 777 & 172 & 80 & 51 \\
\hline Arizona & 10 & $67 \%$ & 1,360 & 1,128 & 172 & 3,728 & 2,586 & 573 & 293 & 219 & 44 \\
\hline Arkansas & 42 & $56 \%$ & 787 & 167 & 620 & 8,092 & 155 & 7,937 & 447 & 11 & 436 \\
\hline California & 56 & $97 \%$ & 7,588 & 4,797 & 1,409 & 18,458 & 9,790 & 4,784 & 979 & 523 & 327 \\
\hline Colorado & 38 & $59 \%$ & 10,406 & 7,914 & 520 & 10,693 & 5,704 & 2,550 & 697 & 356 & 223 \\
\hline Connecticut & 8 & $100 \%$ & 447 & 271 & 152 & 1,592 & 666 & 815 & 96 & 40 & 50 \\
\hline Delaware & 1 & $33 \%$ & 0 & 0 & 0 & 0 & 0 & 0 & 0 & 0 & 0 \\
\hline Florida & 62 & $93 \%$ & 1,154 & 732 & 378 & 17,242 & 5,209 & 11,810 & 996 & 238 & 752 \\
\hline Georgia & 110 & $69 \%$ & 883 & 0 & 883 & 16,305 & 0 & 16,305 & 986 & 0 & 986 \\
\hline Hawaii & 3 & $75 \%$ & 4,504 & 3,025 & 395 & 7,009 & 3,275 & 1,661 & 416 & 161 & 169 \\
\hline Idaho & 43 & $98 \%$ & 1,408 & 1,324 & 52 & 2,723 & 1,843 & 667 & 150 & 96 & 49 \\
\hline Illinois & 78 & $76 \%$ & 4,501 & 0 & 2,138 & 15,025 & 0 & 13,663 & 886 & 0 & 801 \\
\hline Indiana & 66 & $72 \%$ & 2,639 & 678 & 1,960 & 15,004 & 715 & 14,289 & 993 & 60 & 933 \\
\hline lowa & 99 & $100 \%$ & 4,981 & 1,543 & 3,438 & 14,685 & 1,967 & 12,718 & 1,008 & 154 & 854 \\
\hline Kansas & 87 & $83 \%$ & 1,602 & 331 & 1,270 & 6,944 & 835 & 6,109 & 343 & 53 & 290 \\
\hline Kentucky & 103 & $86 \%$ & 1,591 & 378 & 1,212 & 27,193 & 564 & 26,629 & 2,028 & 39 & 1,989 \\
\hline Louisiana & 32 & $50 \%$ & 647 & 11 & 637 & 6,039 & 58 & 5,981 & 334 & 3 & 332 \\
\hline Maine & 16 & $100 \%$ & 938 & 746 & 139 & 14,059 & 2,838 & 10,052 & 721 & 82 & 335 \\
\hline Maryland & 20 & $83 \%$ & 4,975 & 4,540 & 387 & 6,998 & 4,179 & 2,570 & 450 & 272 & 152 \\
\hline Massachusetts & 10 & $71 \%$ & 1,558 & 1,491 & 67 & 2,153 & 1,698 & 455 & 142 & 103 & 39 \\
\hline Michigan & 72 & $87 \%$ & 3,517 & 0 & 2,747 & 23,734 & 0 & 23,709 & 1,440 & 0 & 1,421 \\
\hline Minnesota & 73 & $84 \%$ & 4,147 & 1,493 & 2,655 & 13,900 & 3,654 & 10,246 & 889 & 189 & 700 \\
\hline Mississippi & 47 & $57 \%$ & 1,366 & 1,366 & 0 & 8,138 & 8,138 & 0 & 409 & 409 & 0 \\
\hline Missouri & 114 & $99 \%$ & 2,927 & 0 & 2,510 & 23,007 & 0 & 22,828 & 1,235 & 0 & 1,217 \\
\hline Montana & 30 & $54 \%$ & 1,453 & 735 & 646 & 3,357 & 1,436 & 1,532 & 200 & 86 & 98 \\
\hline Nebraska & 74 & $80 \%$ & 753 & 0 & 753 & 2,576 & 0 & 2,576 & 199 & 0 & 199 \\
\hline Nevada & 11 & $65 \%$ & 886 & 868 & 18 & 1,449 & 915 & 534 & 99 & 70 & 30 \\
\hline New Hampshire & 6 & $60 \%$ & 1,099 & 1,038 & 61 & 1,394 & 1,007 & 387 & 116 & 77 & 38 \\
\hline New Jersey & 15 & $71 \%$ & 1,106 & 459 & 647 & 7,479 & 1,215 & 6,265 & 487 & 79 & 408 \\
\hline New Mexico & 23 & $70 \%$ & 1,547 & 1,169 & 304 & 4,966 & 3,011 & 1,476 & 314 & 180 & 115 \\
\hline New York & 44 & $71 \%$ & 3,918 & 3,869 & 0 & 13,846 & 13,423 & 0 & 752 & 732 & 0 \\
\hline North Carolina & 97 & $97 \%$ & 3,191 & 1,566 & 1,473 & 41,450 & 1,589 & 39,861 & 2,224 & 116 & 2,108 \\
\hline North Dakota & 53 & $100 \%$ & 679 & 0 & 670 & 3,129 & 0 & 3,035 & 237 & 0 & 215 \\
\hline Ohio & 36 & $41 \%$ & 1,698 & 219 & 1,479 & 11,247 & 612 & 10,636 & 684 & 30 & 653 \\
\hline Oklahoma & 73 & $95 \%$ & 2,381 & 756 & 1,625 & 18,660 & 1,070 & 17,590 & 1,007 & 73 & 934 \\
\hline Oregon & 31 & $86 \%$ & 3,654 & 2,237 & 920 & 9,630 & 4,444 & 4,385 & 565 & 229 & 302 \\
\hline Pennsylvania & 29 & $43 \%$ & 3,797 & 3,120 & 542 & 11,819 & 4,422 & 6,984 & 668 & 295 & 363 \\
\hline Rhode Island & 2 & $40 \%$ & 0 & 0 & 0 & 0 & 0 & 0 & 0 & 0 & 0 \\
\hline South Carolina & 37 & $80 \%$ & 2,109 & 1,688 & 173 & 7,523 & 1,245 & 5,174 & 400 & 85 & 263 \\
\hline South Dakota & 59 & $89 \%$ & 1,185 & 0 & 1,185 & 4,179 & 0 & 4,179 & 369 & 0 & 369 \\
\hline Tennessee & 95 & $100 \%$ & 2,718 & 1,513 & 1,145 & 29,367 & 1,026 & 27,734 & 1,596 & 77 & 1,493 \\
\hline Texas & 247 & $97 \%$ & 2,756 & 474 & 2,181 & 21,360 & 1,403 & 19,119 & 1,220 & 72 & 1,130 \\
\hline Utah & 6 & $21 \%$ & 2,011 & 1,990 & 17 & 1,331 & 1,205 & 108 & 87 & 77 & 10 \\
\hline Vermont & 14 & $100 \%$ & 1,746 & 1,281 & 168 & 8,754 & 1,828 & 5,716 & 370 & 115 & 207 \\
\hline Virginia & 57 & $60 \%$ & 2,153 & 1,844 & 309 & 11,364 & 8,218 & 3,146 & 451 & 302 & 150 \\
\hline Washington & 36 & $92 \%$ & 7,705 & 6,293 & 709 & 16,885 & 7,978 & 5,375 & 903 & 366 & 314 \\
\hline West Virginia & 25 & $45 \%$ & 973 & 973 & 0 & 4,165 & 4,165 & 0 & 251 & 251 & 0 \\
\hline Wisconsin & 44 & $61 \%$ & 2,540 & 1,022 & 110 & 8,306 & 2,789 & 557 & 697 & 170 & 42 \\
\hline Wyoming & 13 & $57 \%$ & 1,968 & 1,498 & 470 & 2,383 & 1,194 & 1,189 & 224 & 97 & 127 \\
\hline
\end{tabular}

Source: Rural National Transit Database, 2011 
Table 35. State Financial Statistics, 2011

\begin{tabular}{|c|c|c|c|c|c|c|}
\hline & \multicolumn{3}{|c|}{ Capital Funding } & \multicolumn{3}{|c|}{ Operating Funding } \\
\hline & Local & State & Federal & Local & State & Federal \\
\hline & \multicolumn{6}{|c|}{ - } \\
\hline Alabama & 0 & 0 & 5,289 & 3,768 & 0 & 4,401 \\
\hline Alaska & 0 & 5 & 1,038 & 4,732 & 424 & 5,118 \\
\hline Arizona & 169 & 10 & 5,145 & 4,151 & 596 & 6,874 \\
\hline Arkansas & 0 & 118 & 3,412 & 2,106 & 1,434 & 5,975 \\
\hline California & 1,156 & 4,813 & 6,324 & 32,623 & 14,788 & 13,904 \\
\hline Colorado & 4,837 & 408 & 2,223 & 29,532 & 671 & 7,582 \\
\hline Connecticut & 0 & 250 & 417 & 484 & 1,655 & 1,814 \\
\hline Delaware & 0 & 0 & 0 & 0 & 0 & 0 \\
\hline Florida & 139 & 63 & 2,301 & 4,291 & 7,616 & 10,299 \\
\hline Georgia & 10 & 14 & 9,273 & 9,766 & 97 & 9,128 \\
\hline Hawaii & 346 & 0 & 1,366 & 22,210 & 0 & 2,950 \\
\hline Idaho & 27 & 0 & 5,386 & 2,573 & 12 & 4,043 \\
\hline Illinois & 0 & 0 & 1,633 & 3,933 & 21,995 & 10,042 \\
\hline Indiana & 135 & 0 & 2,259 & 7,352 & 5,588 & 14,906 \\
\hline lowa & 729 & 931 & 4,939 & 5,223 & 6,005 & 9,108 \\
\hline Kansas & 48 & 0 & 249 & 3,001 & 1,906 & 5,242 \\
\hline Kentucky & 92 & 138 & 2,957 & 1,953 & 0 & 12,998 \\
\hline Louisiana & 0 & 0 & 0 & 2,222 & 0 & 7,486 \\
\hline Maine & 279 & 286 & 1,855 & 2,872 & 3,437 & 19,268 \\
\hline Maryland & 745 & 577 & 6,576 & 13,473 & 4,305 & 3,322 \\
\hline Massachusetts & 0 & 1,966 & 7,224 & 1,512 & 2,230 & 2,654 \\
\hline Michigan & 38 & 2,013 & 12,638 & 16,955 & 27,066 & 12,978 \\
\hline Minnesota & 217 & 154 & 3,177 & 365 & 16,259 & 9,679 \\
\hline Mississippi & 0 & 0 & 5,179 & 1,154 & 32 & 5,848 \\
\hline Missouri & 1,145 & 0 & 5,881 & 9,913 & 158 & 11,939 \\
\hline Montana & 192 & 1 & 5,207 & 2,902 & 558 & 4,780 \\
\hline Nebraska & 0 & 0 & 224 & 1,496 & 1,427 & 3,016 \\
\hline Nevada & 117 & 4 & 31 & 3,761 & 20 & 1,995 \\
\hline New Hampshire & 1 & 110 & 2,797 & 1,154 & 305 & 3,622 \\
\hline New Jersey & 158 & 124 & 592 & 10,655 & 7,568 & 2,327 \\
\hline New Mexico & 403 & 0 & 1,669 & 4,774 & 0 & 7,081 \\
\hline New York & 131 & 105 & 5,621 & 8,009 & 13,292 & 4,086 \\
\hline North Carolina & 1,816 & 2,220 & 10,646 & 9,751 & 19,791 & 20,250 \\
\hline North Dakota & 415 & 76 & 2,644 & 988 & 1,946 & 3,169 \\
\hline Ohio & 1,023 & 319 & 11,789 & 4,043 & 3,688 & 14,105 \\
\hline Oklahoma & 25 & 41 & 7,334 & 3,445 & 3,218 & 11,809 \\
\hline Oregon & 708 & 867 & 4,299 & 8,604 & 4,918 & 9,669 \\
\hline Pennsylvania & 586 & 2,619 & 7,321 & 927 & 14,141 & 7,903 \\
\hline Rhode Island & 0 & 0 & 0 & 0 & 0 & 0 \\
\hline South Carolina & 652 & 148 & 5,933 & 3,683 & 1,569 & 4,953 \\
\hline South Dakota & 1,015 & 0 & 6,495 & 2,803 & 991 & 5,785 \\
\hline Tennessee & 483 & 330 & 6,818 & 3,413 & 8,770 & 13,672 \\
\hline Texas & 1,356 & 109 & 10,762 & 2,524 & 12,828 & 21,944 \\
\hline Utah & 520 & 0 & 6,086 & 4,363 & 0 & 218 \\
\hline Vermont & 513 & 479 & 3,334 & 2,002 & 5,840 & 17,296 \\
\hline Virginia & 101 & 1,682 & 2,884 & 6,407 & 2,620 & 9,169 \\
\hline Washington & 2,303 & 1,212 & 11,131 & 34,080 & 11,602 & 7,764 \\
\hline West Virginia & 0 & 146 & 1,104 & 3,818 & 1,317 & 3,453 \\
\hline Wisconsin & 70 & 0 & 3,463 & 2,971 & 5,469 & 8,156 \\
\hline Wyoming & 175 & 416 & 2,313 & 2,922 & 430 & 4,238 \\
\hline
\end{tabular}


Table 36. State Fleet Statistics, 2011

\begin{tabular}{|c|c|c|c|c|c|c|c|c|}
\hline & $\begin{array}{c}\text { Number } \\
\text { of } \\
\text { Vehicles }\end{array}$ & $\begin{array}{c}\text { ADA } \\
\text { Vehicles } \\
(\%)\end{array}$ & $\begin{array}{c}\text { Average } \\
\text { Vehicle } \\
\text { Age } \\
\end{array}$ & $\begin{array}{l}\text { Average } \\
\text { Vehicle } \\
\text { Length }\end{array}$ & $\begin{array}{l}\text { Average } \\
\text { Vehicle } \\
\text { Capacity }\end{array}$ & $\begin{array}{l}\text { Trips Per } \\
\text { Vehicle }\end{array}$ & $\begin{array}{l}\text { Miles Per } \\
\text { Vehicle }\end{array}$ & $\begin{array}{c}\text { Hours Per } \\
\text { Vehicle }\end{array}$ \\
\hline & & & & & & \multicolumn{3}{|c|}{---------thousands--------- } \\
\hline Alabama & 382 & $67 \%$ & 5.1 & 22.3 & 17.7 & 2.6 & 13.9 & .9 \\
\hline Alaska & 100 & $90 \%$ & 4.8 & 28.2 & 20.3 & 18.8 & 26.6 & 1.7 \\
\hline Arizona & 132 & $92 \%$ & 4.8 & 24.1 & 17.6 & 10.3 & 28.2 & 2.2 \\
\hline Arkansas & 404 & $69 \%$ & 5.3 & 21.5 & 11.8 & 1.9 & 20.0 & 1.1 \\
\hline California & 760 & $92 \%$ & 5.8 & 27.2 & 21.8 & 10.0 & 24.3 & 1.3 \\
\hline Colorado & 496 & $87 \%$ & 7.5 & 29.0 & 24.2 & 21.0 & 21.6 & 1.4 \\
\hline Connecticut & 75 & $100 \%$ & 4.9 & 24.0 & 16.4 & 6.0 & 21.2 & 1.3 \\
\hline Delaware & 0 & - & - & - & - & - & - & - \\
\hline Florida & 557 & $83 \%$ & 5.1 & 21.6 & 12.5 & 2.1 & 31.0 & 1.8 \\
\hline Georgia & 713 & $74 \%$ & 3.5 & 21.3 & 13.4 & 1.2 & 22.9 & 1.4 \\
\hline Hawaii & 249 & $85 \%$ & 7.1 & 27.8 & 26.0 & 18.1 & 28.1 & 1.7 \\
\hline Idaho & 141 & $81 \%$ & 6.1 & 25.6 & 18.1 & 10.0 & 19.3 & 1.1 \\
\hline Illinois & 768 & $99 \%$ & 6.3 & 23.3 & 14.4 & 5.9 & 19.6 & 1.2 \\
\hline Indiana & 845 & $77 \%$ & 5.6 & 18.8 & 9.6 & 3.1 & 17.8 & 1.2 \\
\hline lowa & 999 & $90 \%$ & 6.8 & 24.6 & 15.2 & 5.0 & 14.7 & 1.0 \\
\hline Kansas & 358 & $70 \%$ & 6.4 & 19.5 & 11.7 & 4.5 & 19.4 & 1.0 \\
\hline Kentucky & 1,208 & $63 \%$ & 5.2 & 19.6 & 10.5 & 1.3 & 22.5 & 1.7 \\
\hline Louisiana & 231 & $84 \%$ & 7.0 & 19.2 & 10.0 & 2.8 & 26.1 & 1.4 \\
\hline Maine & 245 & $78 \%$ & 7.3 & 24.2 & 17.7 & 3.8 & 57.4 & 2.9 \\
\hline Maryland & 340 & $90 \%$ & 6.8 & 25.4 & 20.4 & 14.6 & 20.6 & 1.3 \\
\hline Massachusetts & 104 & $100 \%$ & 5.5 & 26.2 & 20.3 & 15.0 & 20.7 & 1.4 \\
\hline Michigan & 1,042 & $89 \%$ & 5.1 & 24.9 & 17.5 & 3.4 & 22.8 & 1.4 \\
\hline Minnesota & 470 & $100 \%$ & 5.6 & 25.3 & 17.0 & 8.8 & 29.6 & 1.9 \\
\hline Mississippi & 260 & $77 \%$ & 4.6 & 23.0 & 18.9 & 5.3 & 31.3 & 1.6 \\
\hline Missouri & 791 & $82 \%$ & 5.2 & 20.7 & 11.5 & 3.7 & 29.1 & 1.6 \\
\hline Montana & 232 & $73 \%$ & 7.3 & 24.3 & 16.1 & 6.3 & 14.5 & .9 \\
\hline Nebraska & 175 & $67 \%$ & 5.7 & 20.1 & 11.0 & 4.3 & 14.7 & 1.1 \\
\hline Nevada & 114 & $89 \%$ & 7.6 & 22.5 & 15.1 & 7.8 & 12.7 & .9 \\
\hline New Hampshire & 78 & $100 \%$ & 4.6 & 27.6 & 20.4 & 14.1 & 17.9 & 1.5 \\
\hline New Jersey & 382 & $92 \%$ & 5.7 & 23.2 & 14.9 & 2.9 & 19.6 & 1.3 \\
\hline New Mexico & 284 & $73 \%$ & 5.0 & 22.9 & 15.5 & 5.4 & 17.5 & 1.1 \\
\hline New York & 447 & $98 \%$ & 5.0 & 26.5 & 18.5 & 8.8 & 31.0 & 1.7 \\
\hline North Carolina & 1,376 & $73 \%$ & 4.5 & 20.1 & 11.3 & 2.3 & 30.1 & 1.6 \\
\hline North Dakota & 205 & $80 \%$ & 6.1 & 20.5 & 11.4 & 3.3 & 15.3 & 1.2 \\
\hline Ohio & 541 & $88 \%$ & 4.2 & 19.4 & 9.9 & 3.1 & 20.8 & 1.3 \\
\hline Oklahoma & 880 & $81 \%$ & 4.7 & 20.7 & 12.1 & 2.7 & 21.2 & 1.1 \\
\hline Oregon & 427 & $93 \%$ & 6.4 & 23.6 & 16.3 & 8.6 & 22.6 & 1.3 \\
\hline Pennsylvania & 568 & $100 \%$ & 5.7 & 24.6 & 17.2 & 6.7 & 20.8 & 1.2 \\
\hline Rhode Island & 0 & - & - & - & - & - & - & - \\
\hline South Carolina & 281 & $86 \%$ & 5.7 & 25.6 & 18.9 & 7.5 & 26.8 & 1.4 \\
\hline South Dakota & 389 & $57 \%$ & 8.4 & 20.1 & 12.7 & 3.0 & 10.7 & .9 \\
\hline Tennessee & 1,050 & $79 \%$ & 4.5 & 20.0 & 10.5 & 2.6 & 28.0 & 1.5 \\
\hline Texas & 1,345 & $87 \%$ & 6.8 & 21.3 & 12.5 & 2.0 & 15.9 & .9 \\
\hline Utah & 51 & $98 \%$ & 5.3 & 29.5 & 24.9 & 39.4 & 26.1 & 1.7 \\
\hline Vermont & 243 & $100 \%$ & 4.6 & 26.8 & 20.9 & 7.2 & 36.0 & 1.5 \\
\hline Virginia & 387 & $93 \%$ & 4.0 & 22.3 & 15.5 & 5.6 & 29.4 & 1.2 \\
\hline Washington & 768 & $69 \%$ & 7.5 & 23.8 & 18.2 & 10.0 & 22.0 & 1.2 \\
\hline West Virginia & 232 & $80 \%$ & 4.5 & 22.1 & 14.3 & 4.2 & 18.0 & 1.1 \\
\hline Wisconsin & 349 & $63 \%$ & 5.2 & 20.4 & 9.7 & 7.3 & 23.8 & 2.0 \\
\hline Wyoming & 169 & $79 \%$ & 6.8 & 23.7 & 17.2 & 11.6 & 14.1 & 1.3 \\
\hline
\end{tabular}

Source: Rural National Transit Database, 2011 
Table 37. State Performance Measures, Median Agencies Values, 2011

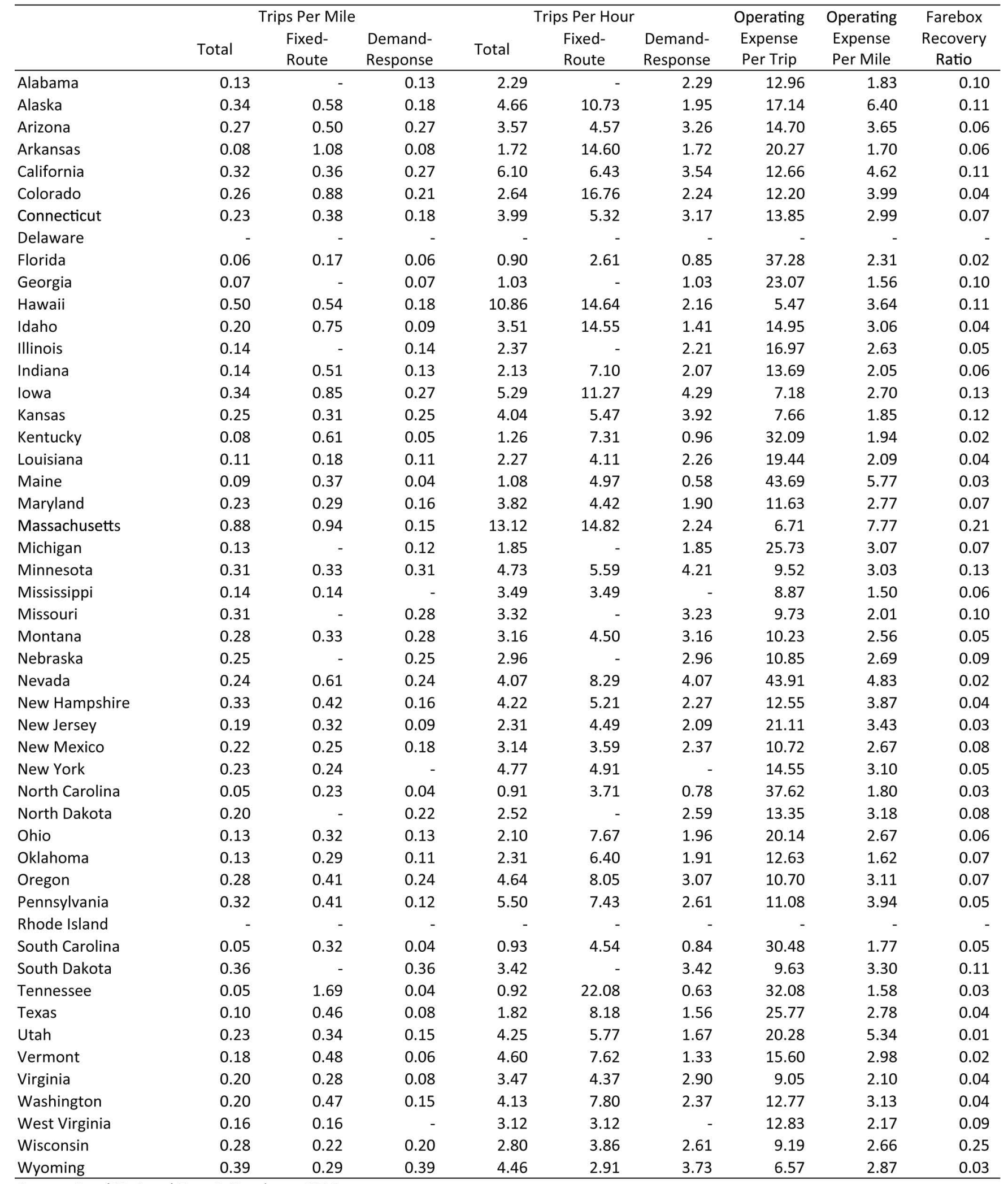

Source: Rural National Transit Database, 2011 


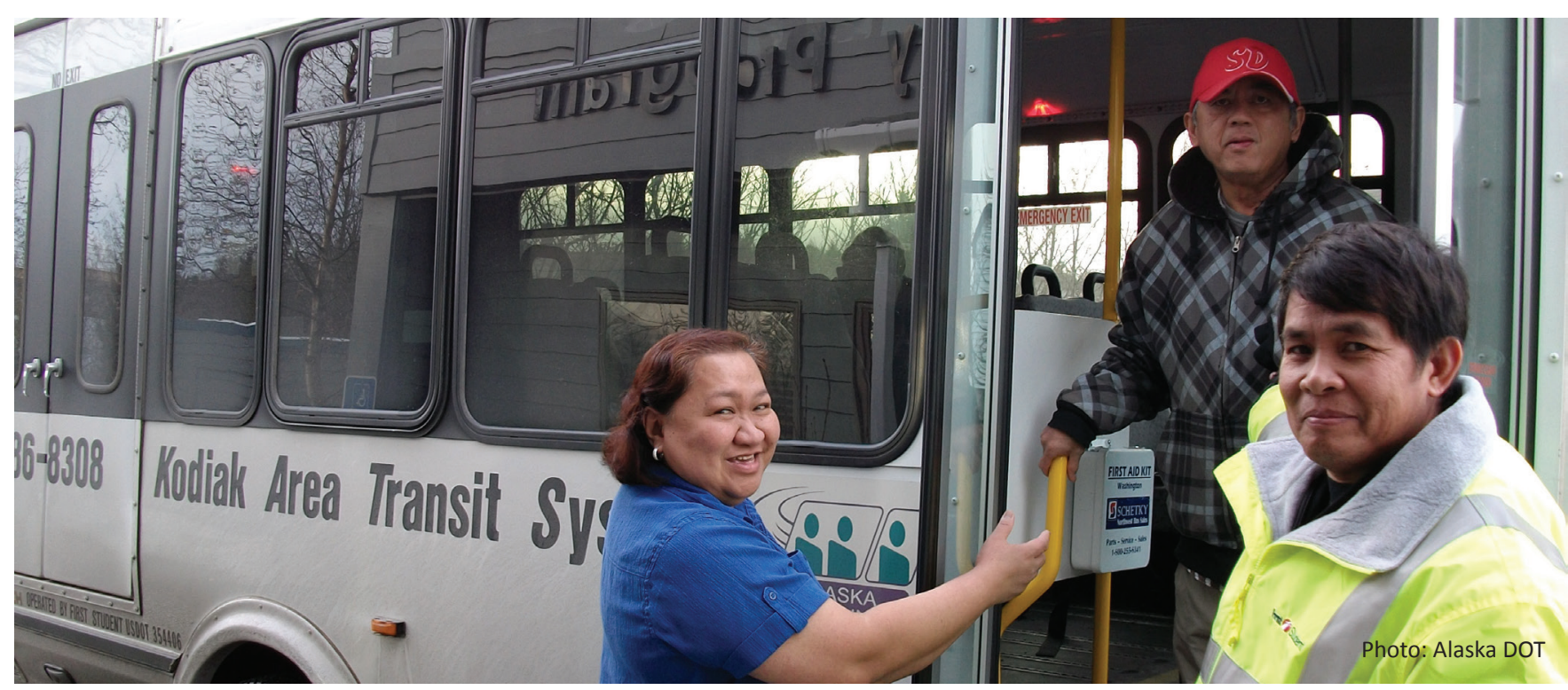

\section{TRIBAL TRANSIT}

The number of tribal transit providers has grown significantly over the past decade (Mielke 2011). A SURTC report published in 201 1, titled "531 1 (c) Tribal Transit Funding: Assessing Impacts and Determining Future Program Needs," provides information about existing tribal transit services and funding and discusses transportation needs of Native American and Alaska Native communities. The report provided data for the 180 rural reservations that had at least 500 residents, showing there are several geographic and demographic indicators that suggest that the provision of transit services should be a high priority on many reservations. These indicators include low population densities, long travel distances, and a higher percentage of older adults and low-income households (see Table 38).

Table 38. Mobility Needs Indicators for Native American and Alaska Native Communities

\begin{tabular}{|c|c|c|c|}
\hline Need Indicator & Standard & $\begin{array}{l}\text { National } \\
\text { Average }\end{array}$ & Tribal Finding \\
\hline Age 60+ & $\begin{array}{l}\text { Percent of population age } 60 \text { and } \\
\text { over }\end{array}$ & $16.3 \%$ & 31 reservations at $20 \%$ or higher \\
\hline Youth & Percent of population age 5-19 & $20.4 \%$ & 33 reservations at $33-38 \%$ \\
\hline Disabilities & $\begin{array}{l}\text { Percent of population with a } \\
\text { disability }\end{array}$ & $7.7 \%$ & no significant difference \\
\hline Income & $\begin{array}{l}\text { Percent of population considered } \\
\text { low income }\end{array}$ & $12.2 \%$ & $33.2 \%$ \\
\hline No vehicle & $\begin{array}{l}\text { Percent of population with no } \\
\text { vehicle in household }\end{array}$ & $10.3 \%$ & 28 reservations at $15-30 \%$ \\
\hline Spent on fuel & $\begin{array}{l}\text { Percent of annual income spent } \\
\text { on fuel }\end{array}$ & $7.8 \%$ & 29 Native counties at $14.8 \%$ \\
\hline $\begin{array}{l}\text { Population } \\
\text { density }\end{array}$ & Residents per square mile & $\begin{array}{l}19.6 \text { residents } \\
\text { per square } \\
\text { mile in non- } \\
\text { urban areas }\end{array}$ & $\begin{array}{l}1015311 \text { (c) recipients average } 15.5 \\
\text { residents per square mile }\end{array}$ \\
\hline Remoteness & Frontier designation & & $\begin{array}{l}225311 \text { (c) recipients have fewer than } 6 \\
\text { residents per square mile, many of which } \\
\text { are located } 50-100 \text { miles from a major } \\
\text { service center }\end{array}$ \\
\hline
\end{tabular}

Source: Mielke 2011 
Figure 6 presents a pictorial of the FTA's 10 regions, the number of tribes in each region, and the number of existing and planned transit operations in each region, as identified in TCRP Project $\mathrm{H}-38$. The number of tribes in each FTA region is based on the tribes listed in the October 1, 2010, Federal Register. Some variations among regions may result because some tribes straddle state and regional boundaries. Based on this TCRP report and start-up grants announced by the FTA in Federal Registers of December 31 , 2009, and March 2, 2011, there are 118 existing tribal transit services, with an additional 45 tribes in the planning stage.

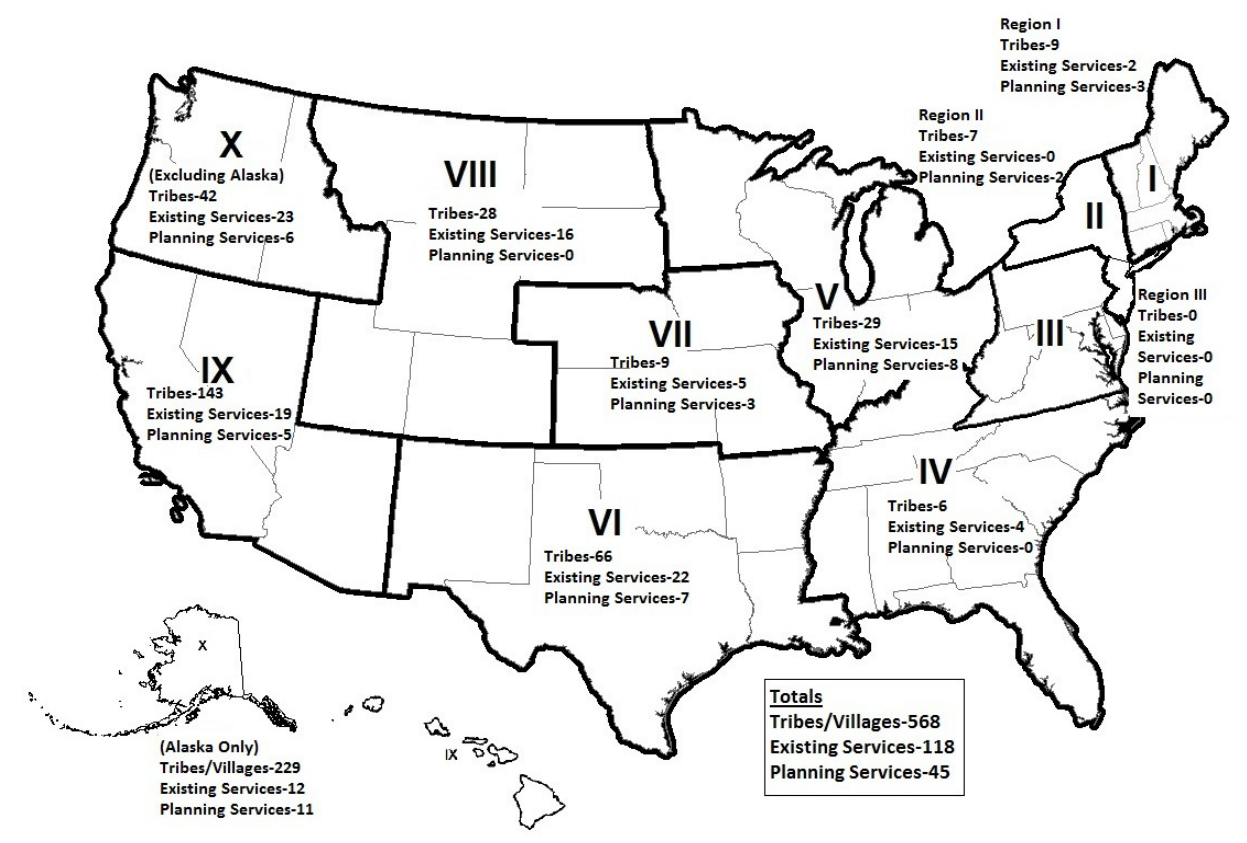

Figure 6. FTA Regions and Corresponding Tribes and Transit Services

Of these rural transit providers, 82 submitted data to the 2011 rural NTD. Statistics for these transit agencies are shown in Table 39. These 82 agencies provided a total of 2.4 million rides in 2011. 
Table 39. Tribal Transit Statistics, 2011

\begin{tabular}{|c|c|}
\hline & Tribal \\
\hline Number of Agencies & 82 \\
\hline \multicolumn{2}{|l|}{ Annual Ridership (thousand rides) } \\
\hline Total & 2,415 \\
\hline Fixed-Route & 1,618 \\
\hline Demand-Response & 705 \\
\hline \multicolumn{2}{|c|}{ Annual Vehicle Miles (thousand miles) } \\
\hline Total & 14,964 \\
\hline Fixed-Route & 8,071 \\
\hline Demand-Response & 5,945 \\
\hline \multicolumn{2}{|c|}{ Annual Vehicle Hours (thousand hours) } \\
\hline Total & 1,033 \\
\hline Fixed-Route & 330 \\
\hline Demand-Response & 669 \\
\hline Number of Vehicles & 456 \\
\hline$\%$ Vehicles ADA & $61 \%$ \\
\hline Average Vehicle Age & 4.2 \\
\hline Average Vehicle Length (feet) & 21.3 \\
\hline Average Vehicle Capacity & 13.5 \\
\hline Trips per Vehicle & 5,295 \\
\hline Miles per Vehicle & 32,817 \\
\hline Hours per Vehicle & 2,265 \\
\hline \multicolumn{2}{|l|}{ Trips per Mile } \\
\hline Total & 0.16 \\
\hline Fixed-Route & 0.20 \\
\hline Demand-Response & 0.12 \\
\hline \multicolumn{2}{|l|}{ Trips per Hour } \\
\hline Total & 2.34 \\
\hline Fixed-Route & 4.91 \\
\hline Demand-Response & 1.05 \\
\hline Operating Expense Per Trip & 13.45 \\
\hline Operating Expense Per Mile & 2.17 \\
\hline Farebox Recovery Ratio & 0.03 \\
\hline
\end{tabular}




\section{REFERENCES}

American Public Transportation Association. A Profile of Public Transportation Passenger Demographics and Travel Characteristics Reported in On-Board Surveys. May 2007.

Federal Transit Administration. U.S. Department of Transportation. 2008-2011 Rural National Transit Database. Retrieved February 2013, from http://www.ntdprogram.gov/ntdprogram/data.htm

Federal Transit Administration. U.S. Department of Transportation. Grants Data. Retrieved March 2013, from http://www.fta.dot.gov/grants/13442.html

Mielke, Jon. (October 2011 ) 5311 (c) Tribal Transit Funding: Assessing Impacts and Determining Future Program Needs. UGPTI Report DP-243, Upper Great Plains Transportation Institute, North Dakota State University, Fargo.

Ripplinger, David, Elvis Ndembe, and Jill Hough. (December 2012) "2011 Transit and Community Livability Report." UGPTI Report DP-262, Upper Great Plains Transportation Institute, North Dakota State University, Fargo.

U.S. Census Bureau. 2009-2011 American Community Survey. Retrieved April 2013, from http://factfinder2.census. gov/faces/nav/jsf/pages/index.xhtml

U.S. Department of Transportation, Federal Highway Administration. (February 2011 ) 2009 National Household Travel Survey, Version 2.1. Retrieved April 2011, from http://nhts.ornl.gov/download.shtml

U.S. Department of Transportation, Federal Highway Administration, Office of Highway Policy Information. Traffic Volume Trends. Various Issues. Retrieved April 2013, from http://www.fhwa.dot.gov/policyinformation/travel monitoring/tvt.cfm

\section{Glossary of Terms}

ARRA - The American Recovery \& Reinvestment Act: Signed into law in February 2009, it included \$48.1 billion for transportation spending, including $\$ 8.4$ billion for transit.

Cutaways - Bus bodies mounted on varying sizes of truck chassis.

Demand-response - Non-fixed-route service with passengers boarding and alighting at pre-arranged times at any location within the system's service area.

Deviated fixed-route - Service in which a vehicle operates along a standard route at generally fixed times, from which it may deviate in response to a demand for its service, after which it returns to its standard route.

Fixed-route - Service in which a vehicle operates along a prescribed route according to a fixed schedule.

Section 5309 - Provides capital assistance for new and replacement buses and facilities, as well as fixed-guideway systems.

Section 5310 - Transportation for Elderly Persons and Persons with Disabilities: Formula funding to states for the purpose of assisting private nonprofit groups in meeting transportation needs of the elderly and persons with disabilities.

Section 5311 - Formula Grants for Other than Urbanized Areas: Provides funding to states for the purpose of supporting public transportation in rural areas with population of less than 50,000.

Section 5311 (c) - Tribal Transit Program: A transportation funding program for Indian Tribes and Alaska Native Villages.

Section 5316 - Job Access and Reverse Commute Program: Address transportation challenges faced by welfare recipients and low-income persons seeking to obtain and maintain employment.

Section 5317 - New Freedom Program: Additional tools to overcome existing barriers facing Americans with disabilities seeking integration into the work force and society.

Section 5320 - Paul S. Sarbanes Transit in Parks Program: Addresses the challenge of increasing vehicle congestion in and around national parks and other federal lands.

Van pool - A ride sharing service to and from pre-arranged destinations in which a number of people travel together on a regular basis in a van which is designed to carry 7 to 15 passengers. 

